\title{
INFORMAL INNOVATION: \\ A HIDDEN SOURCE OF IMPROVEMENT IN WORK AND ORGANIZATIONS
}

\author{
Mia Rosa Koss Hartmann ${ }^{a} \&$ Rasmus Koss Hartmann ${ }^{b}$ \\ a) MIT Sloan school of Management \& Copenhagen Business School (miarosa@ mit.edu) \\ ${ }^{b)}$ MIT Sloan School of Management \& Copenhagen Business School (koss@ mit.edu)
}

MIT Sloan Working Paper Series, \# 5150-15

\begin{abstract}
Informal innovation, defined as the development and putting-into-use of novel solutions by non- $R \& D$ employees without prior formal approval from or subsequent revealing to superiors, has been recurrently observed in organizational research. But even as it is increasingly recognized that $R \& D$ is not the only plausible source of innovation inside organizations, informal innovation has yet to be systematically explored or theorized. We propose a theory of informal innovation based on analyses of prior literature and mixed-method, multi-site studies of innovation at the working level of two extreme-case organizations. We propose that informal innovation occurs as 1) employees personally experience problems that they believe are not recognized or prioritized by superiors; 2) some employees are able to develop solutions, essentially at no cost; 3) innovators face no benefits from revealing to superiors, but can share with peers with no or little effort. In the short term, informal innovation is likely to contribute to local improvements in efficiency and quality of work. In the long term, informality may lead to inefficient and undesirable use of innovations. It may also produce increased intransparency, creating a need for further informal innovation. We discuss the generalizability of these findings and implications for research and managerial practice.
\end{abstract}

\section{Word count: 12,362}

\begin{abstract}
We are grateful to Eric and Jessie von Hippel, Nikolaus Franke, Jeroen De Jong, Michael Tushman, Alfonso Gambardella, Scott Stern and Ethan Bernstein for insights and comments in preparing this manuscript. We also acknowledge the eminent support of the Danish Police and Danish Defense and anonymous expert evaluators in the Danish Police and at the United States Military Academy at West Point.
\end{abstract}

The research was generously supported by The Carlsberg Foundation. 


\section{INTRODUCTION}

Since the beginnings of organization studies, scholars have been aware of the informal dimension of organizational life that seems to inevitably emerge within even the most formalized and hierarchical organizational establishments. This paper focuses on a particular aspect of such informal organization, what we refer to as informal innovation. We define informal innovation as occurring when members of an organization outside of its $R \& D$ functions develop novel solutions and put them into use without formal prior approval, permission or subsequent revealing to their superiors. Such informal innovation has been described in a range of studies within management and sociology, but these studies leave central questions about the phenomenon unanswered: How and why does it occur? What organizational conditions and dynamics give rise to it? Is informal innovation common or marginal, subversive or supportive of organizational goals? Prior work might provide some indications about this, but little more than that. This is the first study that seeks to document why, how and to what extent informal innovation happens in organizations and to provide a systematic theory of the phenomenon.

That innovations can be developed by non-R\&D employees is well-recognized. Research on the forms of knowledge that can contribute to innovation as well as on employees' knowledge in the workplace has shown that R\&D is not the only viable source of innovation within organizations. Even ostensibly unskilled work brings about learning and knowledge that can leveraged for innovative ends. However, there is a clear tendency in studies of innovation outside of R\&D to only construe employees' innovative efforts as proposing ideas to superiors for formal evaluation. NonR\&D innovation, by implication, becomes primarily about its formal variation, while ignoring the informal innovation that we know occurs.

Our findings suggest that informal innovation is widespread at the working level of large organizations and that it is primarily intended to support organizational performance. Typically, it occurs as employees personally experience a problem pertaining to tools or techniques that they use themselves and seek to solve the problem to make their work qualitatively better or more efficient. Yet in spite of the important role played by these innovations in local improvement, a majority of innovations are also informal. Two key dynamics explain this apparent puzzle. For one, employees are able to innovate for themselves very rapidly at tremen- 
dously low cost often using local knowledge and resources already available to them in what is effectively a form of bricolage. They do not, therefore, need managerial support to innovate and do not need to reveal innovation ideas prior to development. Revealing, rather than supporting them, would likely postpone the introduction of a working solution. Second, when employees' innovations solve problems that they experience personally, sharing with managers is unlikely to improve their situation: managers and formal innovation processes are not considered capable of evaluating the merits of innovations or of contributing to improving them. Importantly, managerial evaluations are seen as essentially random and therefore unpredictably related to the quality of a solution.

Our study is conceptually inspired by research on user innovation and draws on a mixed-method research design. As a relatively recent development in innovation studies, research on the sources of innovation have documented the central role played by users in the development of novel solutions and provided important insights into why and how users innovate in ways different from those of producers. Examining prior work on informal innovation, it becomes apparent that much of this is in fact a form of user innovation: employees innovating at work, but doing so in order to solve problems that they face themselves. Early empirical exploration revealed this to also be the case in the organizations that we studied. These were, respectively, two Danish Police districts and the two infantry companies of a Danish Army battalion. Our data comprises field notes, photographs and other material from a total of 24 months of in-depth ethnographic observation of and interviews about the process of developing innovations informally, extensive collection of innovations developed in these organizations, surveys administered to representative samples of employees in them and expert evaluations of identified informal innovations.

This paper not only provides the beginnings of an overarching theory of how and why informal innovation occurs in organizations, but also speaks to the empirical importance of the phenomenon. If generalizable, this carries considerable implications. For research, it suggests a major source and process of innovation within the organization may be hidden, leading to possibly erroneous conclusions about the causes and effects of formal and actual innovation undertaken. For management practice, it suggests that a considerable innovation capacity at both the working level and elsewhere beyond R\&D may not be leveraged for organizational benefit. Benefiting from this capacity, how- 
ever, depends on appreciating the motives and processes of informal innovators as distinct from those of formal ones.

\section{RESEARCH OVERVIEW}

\section{Informal organizations and innovation}

Informal organizations. Almost since the beginning of organization studies, it has been recognized that informal organizing nigh inevitably arises even within the most formalized and bureaucratic of organizations. Barnard (1938), concerned with how coordination and cooperation is achieved in large organizations, suggested that the informal organization will always arise within formal ones and complement them. In the seminal Hawthorne Studies, Roethlisberger \& Dickson (1939) observed that informal organizations form around a sub-set of values among workers that in some cases are compatible with those of the formal organization while in other cases operate in opposition. Other early work suggested that the informal organization enabled individuals to pursue specific interests and values in relation to their work that are disregarded or ignored by the formal organization (Merton 1940; Selznick 1948), while Dalton (1959) even considered the informal organization to be the key to organizational functioning.

However, the question of whether or not such informal organization in general is desirable has been consistently debated - do informal processes impede the efficiencies that hierarchies and bureaucracies are designed to optimize (Weber, 1946; Chandler, 1977), or do they in fact support efficiencies? Roy (1952) shows how informal organizing results in counter-productive arrangements, such as employees tinkering with actual working time and production to avoid and resist managerial intervention, while Mars' (1982) study suggested that actual crimes and cheats were common and tolerated in some work. Later studies of deception, lying and fiddling with numbers indicate the same (e.g. Hunt \& Manning, 1991; Silverman 2012; Wong \& Gerras, 2015). However, informal processes have also been recognized as complementary to the conservatism and slowness of formal organizations. They may, for instance, enable rapid adaptive responses to faced challenges (Firey, 1948; Zurcher, 1965; Chisholm, 1989). The formal organization may be unaware of crucial functions or processes in work, making informal arrangements necessary to get work done (Anonymous, 1948; Berliner, 1956; Bensman \& Gerver, 1963). In this spirit, more recent studies have focused on the 
crucial role played by the informal organization in making various organizational efforts succeed (Nadler \& Tushman, 1980; Morey \& Luthans, 1991; Gulati \& Puranam, 2009; Alter, 2014).

Informal processes in R\&D. Given the role - positive or negative - played by informal organizations, it is hardly surprising that informal processes have been studied and found to be important in organizations' innovation efforts. It is well-documented that research and development (R\&D) efforts often rely on informal social structures to succeed in a range of different ways (e.g. von Hippel, 1987; Kreiner \& Schultz, 1993; Kraut et al, 1990; Aken \& Weggeeman, 2000; Rizova, 2007). Informality is even institutionalized in the 'skunkworks' model of innovation (Rich \& Janos, 2013), where organizations deliberately seek to advance innovation by relieving R\&D of formal demands and processes, which is generally assumed to be an effective mechanism (Tushman \& O'Reilly, 1998; Fosfuri \& Rønde, 2009). Also at the individual level, where individual R\&D scientists pursue projects that are not approved by management (referred to as 'bootlegging' or 'stealth innovation'), it seems to be the case that informal R\&D work is in fact productive to the organization (Augsdorfer, 2005; Criscuolo et al, 2014; Miller \& Wedell-Wedellsborg, 2015). Taken together, there is much to suggest that informality plays a largely positive role in innovation development for both individual inventors and organizations, at least in units that are already officially 'licensed' to innovate.

Informal innovation. When we examine the role of informal processes in innovation outside of R\&D, observations of innovation are scattered across more literatures and findings are less consistent, even if they clearly demonstrate that employees can and do innovate without revealing to managers. The work of Roethlisberger \& Dickson, Roy and Mars all show workers developing innovative solutions, albeit ones targeted at avoiding managerial control and restricting output. Such behavioral innovations appear to be a relatively common form of workplace resistance (Ackroyd, 2012). More positively, Kusterer describes workers occasionally developing improved solutions for doing their work, which is also suggested by various single-case studies (e.g. Morison, 1966; Lindsay, 2010; Kollars, 2014). Orr's study on copier technicians (1996) similarly found that improved solutions were developed, but suggested that this was a very common occurrence and necessary for work to get done. A similar sentiment is often conveyed in studies of communities of practice (Lave \& Wenger, 1991; Brown \& Duguid, 1991) and of work-arounds (e.g. Alter, 2014, Christiansen et al, 2013). Bernstein (2014), in a study of workers in a Chinese electronics assembly plant, found 
numerous self-developed innovative techniques to be used by the workers and suggested that these were a cause of substantial productivity improvement.

The literature on informal innovation, however, opens up more questions than it answers. Firstorder questions about the extent and effects on informal innovation in organizations are unresolved while others about its underlying determinants and dynamics remain largely unexamined. Is informal innovation marginal and trivial, or widely occurring and impactful? Is informal innovation supportive of organizational goals, or subversive to them? We may have hypotheses about these questions and well as about how innovation is actually done at the working level, what forms it takes and why innovation is informal, but we have no systematic studies of the phenomenon on which to base our assumptions about its cause, practice and potential management.

\section{Innovation by employees and users}

Non-R\&D innovation. That employees outside of R\&D can have ideas for innovation is hardly surprising, and this proposition has been the topic of several studies. Indeed, were it not for this dynamic, we should not be seeing much in the way of innovation in organizations without dedicated R\&D functions (Bogers \& Lhuillery, 2006). Examining the relationship between suggestion of innovation ideas by employees and the implementation of those ideas, Axtell et al (2000) examined what factors lead shopfloor employees to propose ideas and what lead ideas to be formally implemented. Jensen et al's (2007) seminal study on the forms of knowledge that gives rise to innovation posits the centrality of the knowledge that develops in the course of everyday work and accrues from experience and documents organizations' efforts to tap into practice-related knowledge through formal arrangements. A recent body of work on employee-driven innovation (Kesting \& Ulhøi, 2010) and Høyrup et al (2012) has similarly advocated that 'licenses' to foster innovation should be extended and employees actively engaged as potential contributors to the innovation processes of the organization.

This work departs from a learning perspective on work, highlighting how the 'doing' of work and participation in professional communities of practice (Lave \& Wenger, 1991) brings about a distinctive form of knowledge and that innovations may emerge within practice based on this unique knowledge. In doing so, it essentially follows Braverman (1974) and Kusterer (1976) and an anti- 
Taylorist perspective of describing even 'unskilled' work as skilled practice. Orr's ethnography (1996) is instructive in demonstrating both how work inevitably requires workers to be much more skilled than their managers assume or even know about and how, because of these skills, workers are able to develop solutions to the problems that they face in performing their work. Working, learning and innovating may, therefore, be fundamentally integrated (Brown \& Duguid, 1991). This is the sentiment underlying the original formulations of a management concept like Total Quality Management, where employees' ideas play a major role in kaizen and process innovation initiatives.

What is surprising in much of this literature is the view that employees merely have ideas and then propose them and not, as Orr (1996) or Brown \& Duguid (1991) implicitly describe it, actually turn ideas into novel practices. If we examine the scattered descriptions of informal innovation, it also becomes apparent that employees do not merely have ideas, but engage in the entire innovation process by developing functioning prototypes, implementing them in their work and using them, all without the awareness or support of management. They do not, it would seem, only possess 'problem-related' knowledge gleaned from their working experience, but also sufficient 'solutionrelated' knowledge to turn those ideas into working solutions.

User innovation. Much of the literature on informal innovation can be interpreted through the lens of a relatively recent literature on 'user innovation'. Examining the sources of innovation, this work has shown that users play an important, if not dominant, role in innovation development in many fields (reviewed in von Hippel, 2005; Bogers et al, 2010) and in the general population (de Jong, 2016), and that users differ markedly from producers in several respects, including how and why they innovate. Users typically innovate to address unmet needs (von Hippel, 1988) and execute a given practice more effectively (Hienerth, 2006; Lettl, 2007). Such needs may not be recognized by producers (von Hippel, 1986), they may be too heterogeneous to cater to (e.g. Hyysalo \& Usenyuk, 2015; Franke \& von Hippel, 2002), or the knowledge required to solve them may be so tacit and hence costly to transfer that it cannot be solved effectively by non-users (von Hippel, 1994). For this reason, users may focus more on novel functionalities than on dimension-of-merit improvements when innovating (von Hippel, 1976; Riggs \& von Hippel, 1994). They may also rely more on practice-based knowledge of problems and whatever technical solution-related knowledge is al- 
ready available to them (Luthje et al, 2005), rather than on 'new to the world' technological insights.

Given these differences, user innovation has been described as paradigmatically different from the dominant Schumpeterian understanding of how innovation occurs. This paradigm emphasizes paid and profit-seeking innovators developing solutions for others, while that of user innovation emphasizes that innovation can be self-rewarding in the sense that personal use or benefits of the innovation process itself is sufficient to motivate the innovator (Baldwin \& von Hippel, 2013).

Indeed, it is evident in many cases of informal innovation that employees are developing solutions that they themselves need and will benefit from using, making them conceptually similar to the user innovators that are typically found beyond the boundaries of formal organizations. The professional communities, or communities of practice, that employees partake in within formal organizations are also conceptually similar to those of user communities found in private settings (von Hippel, 2005). Within their communities, users tend to self-select into the type of innovation development that they can efficiently do themselves, i.e. by relying on the knowledge that they already have, while generally leaving those solutions that would be difficult for them to do individually for others to pursue (Luthje et al, 2005; Hienerth et al, 2014), thus informally dividing and allocating innovation labor. Typically, very innovative users are likely to be known by others within these communities (von Hippel et al, 2009), much like how employee-innovators are known and respected within their communities of practice (Kusterer, 1978; Orr, 1996; Bobrow \& Whalen, 2002).

\section{EMPIRICAL APPROACH}

The methods used in this study combine ethnographic observation and interviews in police and military organizations with a range of quantitative data, namely surveys, innovation samples and expert innovation evaluations. This mixed-method approach was chosen to gain access to and explore in detail the informal innovation context and practices of working-level employees, while also seeking to gauge the empirical extent and generalizability of the theoretical dynamics observed. Such a mixed-method approach, allowing for simultaneous use of complementary forms of data, helps reduce the risk of errors and biases resulting from one specific approach (Axinn \& Pearce 2006). 
We selected police and military organizations as settings for this study of informal innovation for three reasons. First, both types of organizations are large and bureaucratic in nature and highly focused on uniformity in both appearances and practices. In this respect they epitomize inhospitable conditions for variation and difference (e.g. Arundel et al, 2015). Second, the innovation that does occur within them is typically assumed to occur according to very particular protocols and with a strong focus on standardization across the organization (e.g. Lindsay, 2010). Third, both types of organizations emphasize inspection and inspectability in operations to ensure managerial control and democratic transparency and have far-reaching opportunities for sanctioning employee deviance and resistance (e.g. Hartmann, 2014). Taken together, these characteristics make our empirical settings adverse not only to innovation, but especially to a form of innovation that is developed without prior managerial approval and, once developed, used in ways that are hidden from management. They constitute extreme-case settings for the phenomenon under study (Yin, 2009). For practical purposes relating to access, the organizations studied were Danish.

\section{Research settings}

We studied two sites in the Danish Police, namely 'Country' and 'Metro', and two in the Danish Army, 'Alpha' and 'Bravo'. Within the extreme-case setting of police and military organizations, these sites were chosen for their typicality - to the extent that one can speak of ideal typical exemplars of Danish Police districts and Danish Army units with respect to core tasks and conditions for doing that work, those were what we sought out. Within both police and military, it is possible to find sub-units that deviate dramatically from the bureaucratic and standardized form (e.g. police task forces or military special operations units), but these were deliberately avoided.

Country. Country is a police district comprised of several midsize towns and the rural areas between them. The first author conducted field work at three sites within the district over a total period of six months as an 'intern', rotating through the different police stations of the district and taking part in daily work, including standard patrols, police raids, training exercises for police officers and managers, investigation work and police dog training at all times of operation. In addition to informal interviews and observations, 59 taped, in-depth interviews were conducted with individual and groups of rank-and-file officers, police managers and administrators, each interview lasting between 45 minutes and two hours. 
Metro. Metro is an urban police district. Within Metro, the first author conducted field work at two sites. First, the researcher spent 3 months in an inner-city patrol unit of approximately 300 police officers spread out in three groups as well as morning, afternoon and night shifts. The work of these patrol officers consists of patrolling the streets, responding to alarm calls and documenting incidents for the investigative and legal processes. The second site was a local investigation unit of nearly 40 detectives also working in shifts, where the researcher spent another 3 months following the detectives as they gathered evidence on crime scenes, interviewed suspects, wrote up cases etc. The researcher participated in all aspects of round-the-clock operations.

Alpha and Bravo. Alpha and Bravo are infantry companies of an armored infantry battalion and are ostensibly identical in organization. They are the most typical infantry unit in the Danish military and each consist of approximately 125 people, most of whom are infantry soldiers trained to be deployed in different types of armored, tracked vehicles. A fraction is also composed of support personnel, e.g. mechanics or logistics personnel. In both units, all soldiers are professional (i.e. not drafted) and most have served tours of duty in international missions. The second author participated in all aspects of daily work for six months in each organization, which consist primarily of training activities, participation in off-base and international exercises and garrison duty. While studying Alpha and Bravo, the researcher also spent a short period with the garrison's vehicle maintenance unit and with a specialized sniper unit associated with Alpha and Bravo's battalion. Prior to the study, the researcher had served for a two-year period as a military officer in a different branch of the Danish Army.

\section{Data collection}

Ethnographic fieldwork. The ethnographic component of the study provides the detailed insights into the dynamics of informal innovation. In organizations, ethnography can provide the researcher with in-depth understandings of organizational life, including such elements as (micro-)politics, power-relations and other subtleties that are difficult to capture with other methods (Neyland, 2008). During the process, the researcher and the members of the organization jointly elaborate their understanding of what goes on in the organization and why (Alvesson \& Karreman, 2007; Van Maanen 2011). In contrast to quantitative measures focusing on the extent and prevalence of a phe- 
nomenon, the qualitative focus of ethnographic research is the specific rather than the generic as it aims to answer the what, how and why of a studied phenomenon (Maxwell 1992; Van Maanen 2011). It involves engaging with people in the field over extended periods while access is constantly (re)negotiated. It took a considerable amount of effort to build the kind of trust needed to access the actual everyday work spheres of police officers and soldiers. During the total of 24 months of fieldwork that inform this study, extensive field notes were taken during the course of everyday participation. Notes were typically recorded during breaks, because both soldiers and police officers often felt uncomfortable with notes being taken during conversations. For the same reason, many ethnographic interviews were not recorded - many preferred not to speak directly to a microphone, given that the topic of many interviews concerned violation of organizational rules. Instead, notes were taken after the interview. Perhaps surprisingly, there were fewer reservations about being photographed, and so several thousand photos were taken as supplements to the field notes. Throughout the progress, the two researchers shared notes and photos and discussed observations on a daily basis.

Interviews and innovation samples. As part of the study, we gathered two samples of innovations, 40 solutions developed and used by the police officers and 98 by the soldiers. This was an iterative process where we learnt that in order to engage informants in mutually meaningful conversations, the word innovation had to be substituted for a vocabulary that reflected that of the respondents. We learned to frame our focus as one of looking for "any solution that you or a colleague developed yourself' and then later sorting between actual innovations, what was only at the idea stage or copies of other solutions. To the respondents, the utility of a solution was key - it was less important whether a solution was acquired, or whether a similar solution already exists in a different form (such as when the soldiers produce a cup holder for their vehicles from a cardboard tube inside a roll of tape).

When respondents heard that we studied 'innovation', they would often assume that we were looking for groundbreaking new technologies. Also, they often felt uneasy about showing unofficial solutions that they might get in trouble for using if managers were tipped off. We also emphasized that it really didn't matter how 'small', 'ugly' or 'unofficial' it was, since some informants were reluctant to show us their own solutions because the prototype they had developed was very rough (what in both settings are known as 'duct tape solutions'). When more details were needed about 
the solutions we engaged informants in semi-structured follow-up interviews and informal chats at a time and place of their convenience. In the course of such follow-ups, photographs were also taken if acceptable to the informants.

We continued collecting examples and stories about innovations until we achieved a 'point of saturation' where there was not much new to the examples and stories we were told and the descriptions we needed were 'thick' with detailed context (Geertz, 1973) for a deep understanding of the functions and social implications of each innovation.

Surveys. At the end of the fieldwork, a survey was administered to representative samples of organizational members in Metro's investigation unit, Alpha and Bravo. With contextual modifications, the survey followed the approach of von Hippel et al (2012) and De Jong et al (2015) to identifying consumer innovators. Respondents identified as innovators were asked follow-up questions concerning their most recent innovation to further ensure representativeness, i.e. to avoid that only the most important innovations developed by the individual innovator were subject to further questions.

The surveys were filled out electronically or on paper during allotted time in the respondents' workday. In Metro, the survey was given to the participants in morning meetings for all investigators, where they were also served breakfast and pastries by the researcher as traditionally called for when police officers are asked to do something beyond their immediate job prescription or selfinterest. In the military, each of the platoons ( $\sim 30$ individuals) in the two companies had the activity scheduled during a day in garrison otherwise dedicated to instruction in the use of M60 machine guns or vehicle maintenance. This was done to ensure that a representative sample of organizational members filled out the survey. In Metro, 86 responses were collected, in Alpha 74 and in Bravo 71, totaling 231 responses. Of these, 26 were not completed, giving a response rate of $89 \%$ with 205 completed surveys. The non-response rate was considerably higher in Metro than in Alpha or Bravo, owing to faltering Internet connections. Police officers who lost connection to the survey website restarted the survey and their unfinished responses were discarded.

Expert evaluations. Because of concerns for anonymity, it was not possible to share the innovations of the respondents with their immediate managers to have their merits and value to the organization assessed. To instead provide a 'proxy' for managerial evaluation, we assembled two expert 
panels to evaluate the innovations developed in the police and military respectively. The police expert panel was composed to two civilian topical experts with current or former affiliation with the Danish National Police and one practicing managers from a police district other Country and Metro. The military expert panel was composed of four instructors at the US Military Academy at West Point ${ }^{1}$ (three officers and one master sergeant), all with personal experience leading units similar to Alpha and Bravo. These panels evaluated the 40 innovations from the police innovation sample and a subset of 56 innovations from the military sample ${ }^{2}$, using a standard set of questions relating to the value and utility of the innovations.

\section{ANALYSIS AND FINDINGS}

In this section, we first describe the occurrence and nature of innovation amongst working level employees. In the second part of the analysis, we describe the motives for innovators to develop innovations. Then, we examine the extent to which innovations are informal, i.e. developed without the involvement of managers and not shared through the formal system, and offer theoretical explanations for this informality.

\section{The scope of innovation at the working level}

At the working level of the organizations studied, innovation is a common, but often unarticulated, activity. Spend a proper amount of time with any soldier or police officer and they may very likely demonstrate a non-standard solution that they themselves or a colleague has developed or purchased, such as a short-cut procedure, non-issued equipment and improvised techniques for performing their variety of tasks. These solutions will frequently be the subject of collegial discussions but will rarely be referred to as 'innovations', which to the soldiers and police officers is more of a

\footnotetext{
${ }^{1}$ Although less than ideal, we were forced to rely on non-Danish evaluators. This was the case because it proved impossible to anonymize the soldiers who had developed innovations sufficiently to use a Danish panel of experts (the nature of the innovations meant that in some cases, there were only six possible developers in the entire Danish Army). Relying on non-Danish evaluators clearly confounds the evaluations (because different militaries use different technologies and therefore experience different problems). We sought to off-set this problem by having evaluators who had served in functionally identical units in the American Army and in similar theaters.

${ }^{2}$ This subset comprised all the innovations developed in Bravo Company. Bravo company was chosen, because this was the company with the largest number of innovations of the two studied No other selection criteria were applied. Owing to limitations in the time that evaluators could spend on the project, only a sub-set of innovations were evaluated.
} 
management buzz-word. Instead, 'innovations' are described in other terms, like 'creative solutions', 'nice stuff', 'things that make work easier or better' and often innovations are displayed with some measure of pride.

What we found when identifying innovations was that people develop and use at the working level was generally - but not at all exclusively - either tools or techniques that they themselves need in their work, with tools understood broadly to refer to any kind of physical items that police officers or soldiers need to accomplish work (e.g. uniforms, equipment, weapons, vehicles, etc.). A police officer, for instance, developed and organized an online platform for victims of violent crimes. Exemplary innovations are presented in Table 1.

INSERT TABLE 1 ABOUT HERE

INSERT PICTURES 1-10 ABOUT HERE

The surveys confirm this general pattern. More than $80 \%$ of all respondents reported having made either solutions or modifications that have been put into use within the past 5 year period, with more than $90 \%$ of respondents in Bravo having done so. Screening out 'false positives' following the approach of de Jong et al (2015) with slight adaptations to account for the work-related nature of innovation in this study, $35.6 \%$ of all respondents were classed as actual 'innovators' (see table 2 and figure 1). Asked about the number of solutions they have developed, $87.6 \%$ of confirmed innovators report to be serial innovators, having developed on average $\sim 4$ solutions $^{3}$ in the preceding five years (see figure 2).

\footnotetext{
${ }^{3} 9$ respondents developed 1 innovation, 40 developed 2-4, 13 developed 5-7 11 developed 8 or more, i.e. $(9 * 1+40 * 3+13 * 6+11 * 8) / 73 \approx 4$.
} 
INSERT FIGURE 1 ABOUT HERE

INSERT TABLE 2 ABOUT HERE

INSERT FIGURE 2 ABOUT HERE

Across all the organizations studied, innovators most commonly report having developed solutions related to gear and equipment, comprising many of the tools used in daily work. Clothing (in the form of uniforms), vehicles and weapons are also tools that are often subjected to the attention of innovators, while operative techniques are developed and modified by a small, but still considerable number of innovators. Reflecting that police investigators have more office work than soldiers, administrative processes and IT are much more frequent types of innovation developed and modified in Metro than in Alpha and Bravo, where weapons and vehicles are play a much larger role and are subject to greater innovative efforts.

INSERT TABLE 3 ABOUT HERE

\section{Motives for innovation}

Given the disciplinary incentives for working-level police officers and soldiers not to innovate (in both organizations, employees can be punished for using non-issued solutions, as we will return to) what are the motives that incite them to do it anyway? 
Both the police officers and soldiers report that they primarily develop new solutions for their own use at work, i.e. that they are user innovators. This is not the case for all, as a small group of innovations were developed to help others who the innovators became aware had a problem. Consider, as illustrative of innovating for oneself, the following example. In the police, the local police officers are only issued uniformed clothing and standard equipment, including a belt designed for carrying pistol, pepper spray and handcuffs, which is not only bulky but designed specifically to sit at the hip and on the outside of one's clothes. This means that whenever a police officer is on a plainclothes assignment, she risks being identified as an officer, because this belt cannot be hidden beneath civilian clothes. In order to save themselves from the risk of being revealed, police officers come up with a variety of solutions to these problems. For example, a police officer bought an oversized elastic belt and had his mother sew pockets for his gear in it. In this way he could wear it around his waist underneath a jacket or sweatshirt and thus remain inconspicuous (this solution is also described in table 1).

\section{INSERT PICTURE 11 ABOUT HERE}

Employees who report that they have innovated for their own use are often motivated by figuring out ways of improving their performance, rather than simply by solving their private needs. Reflecting this, over sixty percent of innovative survey respondents state that they innovated in order to do their work more effectively or to improve its quality, while over forty percent claim that they innovate to compensate for the shortcomings of formal solutions.

INSERT TABLE 4 ABOUT HERE

A particularly paradoxical motive for innovating, albeit also a quite rare one, is to be able to follow formal rules. A military mechanic, for instance, is tasked with the maintenance of the heavy machine guns used in his unit (also described in table 1). As part of routine maintenance, a buffer on the gun must be adjusted by screwing. According to the manual specifying the maintenance proce- 
dure, this buffer must be adjusted to a certain torque level. However, there exists no tool capable of doing this: there is a tool that will fit into the buffer mechanism on the gun and allow it to be turned, but this tool cannot be used with a torque wrench. Consequently the mechanic develops his own tool to solve this dilemma imposed on him by official regulations.

It is highly salient for most respondents that their innovations effectively 'hide' the problems they experience from their superiors. As a police officer says: "Actually we shouldn't do all of these things to save the system from itself. Because every time I say: "okay, to hell with it, I buy it or fix it myself" I really just add to the lack of solidarity for improving things as when the managers look the other way when we tell them that we need this and that to do our job". In the case of the undercover belt, the police officer and his colleagues might as well just have refused to enter places that would jeopardize their safety unless they were provided with the proper equipment. But they don't refuse, choosing instead to execute the task, because what drives them is the job of keeping their city safe. Similarly, the military mechanic could choose to just not perform maintenance. Professional pride, however, seems to make such passivity undesirable: these tools and techniques are needed to do work in a satisfactory manner.

Survey respondents were asked to evaluate the importance of their solutions to their own and others' work in the organization. The innovators generally agreed that their innovations are important for them in doing their job, while more than a third are evaluated as very important, even essential, to performing one's job (table 5). These evaluations are reflected in their evaluation of how valuable it would be to others in the organization.

\section{INSERT TABLE 5 ABOUT HERE}

Besides its functional value, an innovation can also be symbolically indispensible to the innovator, such as if an employee feels uncomfortable with the thought of facing a particular task that he or she is unable to handle without that specific solution. Even if this is less openly voiced and possibly less salient to the innovator, it is nonetheless an important dimension of utility. One police officer always carried a small tool in his pockets that he had modified for breaking windows (also de- 
scribed in table 1). He explained how he had once struggled to break a car window to get the people inside of it - a mother and her child - out after a car crash. The mother was unconscious and therefore unable to unlock the car from the inside. Afraid that the car would catch fire due to the serious damage to it, the police officer had desperately struggled to break the tough car window since a window breaker tool is not included in the issued standard multi-tool in the police. After that, he would never be on duty without his homemade window breaker tool although the police managers do not approve of officers carrying around unauthorized tools in their pockets. While some of his colleagues had a similar tool in their pockets, others felt that it was unnecessary because one could probably always find something on the scene that would break a window.

\section{Informal innovation: Scope and causes}

When you look for innovations at the working level, what you invariably see is what we describe as informal innovation: people will develop solutions on their own initiative and will typically share neither ideas nor developed solutions with their managers. When, during our field work, we asked whether managers had been asked for permission before a solution was developed, we would typically be met first with incredulity and then provided with the short-hand explanation that it was “easier to ask for forgiveness than permission". Similarly, when we asked if managers might be aware of an innovation, we learned from both police officers and soldiers that in many cases they would actually actively hide their solutions from managers. Others would simply not bother to inform managers. And some believed that managers would never notice; such as in the case of a soldier driving his company commander's personal armored personnel carrier (in which the commander would spend most of his time while the unit was on week-long exercises) explaining that the commander had no knowledge about the vast amount of modifications that his personal driver had made to the vehicle. He believed his solutions to be 'hidden in plain sight', even as the commander sometimes also used the innovations.

In fact, it is exceedingly rare for innovators to seek permission to develop and use solutions, at least in the settings studied. Of the innovators surveyed (see table 6), less than ten percent developed their solution according to formal procedure and after seeking permission through the chain of 
command ${ }^{4}$. Sharing with managers was certainly more common, but ultimately more than half of respondents reported not having followed formal procedure and not having shared with their managers and that managers were ignorant of their innovation ${ }^{5}$. A majority of the innovation actually occurring at the working level thus fits our definition of informal innovation (the scheme for coding innovations as informal is illustrated in figure 3), meaning that it is per definition not known by the formal organization (95-percent confidence interval is between 41.7 and 65.7 percent of innovators). Instead, they are shared amongst and adopted by peers. $67.9 \%$ of innovators reported knowing that their innovations had been adopted by colleagues in their own unit and $32.1 \%$ reported adoption by colleagues in other units (see table 7).

INSERT FIGURE 3 ABOUT HERE

INSERT TABLE 6 ABOUT HERE

INSERT TABLE 7 ABOUT HERE

Why innovations are developed informally. Why, if innovations are developed to do work better or more effectively and thus in the apparent interest of the organization, are they developed informally? For the innovators observed in our ethnographic studies, formal development is rarely even considered to be an option. Instead, police officers and soldiers consistently talk about developing solutions and modifications 'under the radar' and without even involving managers in the development. We observed two mutually reinforcing dynamics behind this: workers' ability to self-produce

\footnotetext{
${ }^{4}$ In the paper version of the survey, one respondent wrote "WTF! Does anyone ever do this?" next to the field to be checked by those respondents who followed formal procedure.

5 The questions 'Who knows about this solution' and 'With whom have you shared this solution' were presented with the opportunity of selecting more than one answer and prompted for 'Managers in my own unit', 'Managers in other units' and 'Case officers/administrators' (Danish: 'Sagsbehandlere'). If the respondent selected either of these options, they were classed as formal innovators.
} 
good-enough solution and their view of the organization. When workers encounter a problem, they may be able to solve it to a satisfactory degree themselves, even with a relatively limited investment of time and energy. Relying on their organization and its formal processes to solve the problem involves not only a large effort with highly uncertain outcome, but also enduring the problem while awaiting a solution.

When, in the survey, innovators were asked why they had chosen to develop their innovations without following formal procedure, three reasons stand out (see table 8). The most common reason, selected by $46.2 \%$ of innovators who developed their solutions 'under the radar', concerns the urgency of the experienced need. Recall that the majority of innovators are user innovators, solving problems that they themselves experience, typically on a daily basis. The prospect of waiting for the organization to provide a solution can be particularly unattractive, especially in situations where personal safety is concerned and when the problem is faced constantly. Consider here the police officers' need for an equipment belt suitable for undercover operations previously described or soldiers facing the risk of IED's during patrols performed on a daily basis.

For the worker experiencing a problem and having a solution in mind, this concern will interweave with at least two other important concerns for those developing solutions informally, namely the opacity of the formal process (for 29.2 percent) and the perceived lack of interest in their problems (for 23.1). For an operating-level worker, the organization easily appears overwhelmingly large and bureaucratic and finding the right person to propose your idea to can be difficult, even for those who have accumulated a knowledge of the formal organization over many years of tenure: managers in the police and military change positions relatively often and organizational changes redistribute tasks and areas of responsibility. If the right person is identified, those people are less likely to take seriously a suggestion coming from an operating-level employee, simply because they typically get approached by at least middle-managers. And, should one be taken seriously, a suggestion will typically have to be described in writing in order for it to be evaluated. This process is not only time-consuming, but also frustrating, especially in the case of very tactile solutions that make much more sense when demonstrated 'live'. 


\section{INSERT TABLE 8 ABOUT HERE}

It is also a process with uncertain outcomes, because managers are not expected to understand or recognize the problem. In the military, managers are often described as "academics, not craftsmen" and as interested in the "tactical decisions that they are making", not details of how a soldier executes a particular function. In Metro, where most top managers have a legal background, university educationsand no police training, police officers are very explicit about this as well - only some managers, typically with a prior practical policing background, will be expected to understand the nature of an experienced problem. In effect, police officers and soldiers here describe the problem of "sticky information" (von Hippel, 1986) and the discrepancy between work as imagined and work as it is actually done (Brown \& Duguid, 1991), implying that engagement in their work is a precondition for recognizing the problems inherent to it.

These concerns alone, however, would not lead a worker to develop solutions were it not for a central dynamic, namely that developing solutions without managerial support is actually a viable possibility. While it is sometimes assumed that innovations are dependent on some measure of managerial support, at least in the implementation phase, this does not seem to be case when we examine the resources required to innovate. Innovators' survey responses (summarized in figures 4-6) show that the median pecuniary investment to develop a solution was 0 ; the median amount of work and leisure time is less than an hour and zero, respectively. Innovators, in other words, are tremendously efficient when developing their solutions, especially relative to the importance that innovations can have for their work: the typical innovations is developed at essentially no cost.

How can innovations be realized with so limited resources? Essentially because of bricolage (LeviStrauss, 1966; see also Pina e Cunha et al, 2014, or Baker \& Nelson, 2005). Police officers interviewed would frequently refer to what they called 'the principle of the nail at hand': in order to do a job, you sometimes must use whatever tools are available. They would invoke this principle when explaining how they go about innovating, which primarily happened by using things they already knew and whatever tools and materials that they could get access to without too much trouble. We can understand this phenomenon of innovators needing very few resources as reflective of two 
things. For one, the working environment may be 'rich' in tools and materials that can be exploited for innovation, as is clearly the case in the military. Second, the working knowledge (Kusterer, 1978; also Brown \& Duguid, 1991; Orr, 1996) that is locally already available to workers is often sufficient for them to develop solutions. It is well-known that users when innovating will tend to rely on 'local' knowledge that they already have available (Luthje et al, 2005) rather than actively seek out new knowledge. Or, in the inverse, solutions will only be developed if the knowledge, tools and materials needed to create innovations are already available in the environment and can be bricolaged into working innovations; if this is not the case, an innovation opportunity may simply not be pursued because the ideator self-selects out of the process. However, the requisite combination of knowledge, tools and materials appears to often be available.

INSERT FIGURE 4 ABOUT HERE

INSERT FIGURE 5 ABOUT HERE

INSERT FIGURE 6 ABOUT HERE

Where do these resources come from? In both Alpha and Bravo, each company has a workshop where its mechanics have their tools. Other soldiers, who the mechanics trust to not hurt themselves, will be allowed to use those tools. The workshops, as well as the garages where the unit's vehicles are parked, also contain many spare parts that may be intended for a specific purpose, but which may just as well be used creatively. The police officers, by contrast, generally do not reside in as rich an environment as the soldiers do, but will then often rely on things that are privately available. Many innovations developed in Metro that relate to clothing and textile equipment involve the police officer's mother and her sewing machine, while fathers, friends and family play helpful roles in other types of innovation production. A police officer who needed a small piece of 
software, for instance, had a friend skilled in programming. In exchange for the police officer driving his friend's son to soccer practice, the friend wrote the software. Generally speaking, in the situation where the soldier or police officer cannot quite design and produce a solution him- or herself, help is usually at hand.

Because of this resource-constrained development process, innovation will often be visibly 'rough' and not as durable (and safe to use) as would be ideal. The machine gun tool (see table 1) was not as strong as required by common standards (e.g. CE-certification) and might break if applied with excessive force. It is for this reason that the tool is painted yellow to make it plainly visible to others that they much be used with caution, a common practice amongst military mechanics. A flashlight holder used in Metro, similarly, is clearly not professionally made (see pictures 13a and 13b). It turns out, however, that this is hardly a problem for the innovators, because the functional purpose of the innovation can be achieved in spite of this roughness. Survey responses to the hypothetical question of how much better an innovation would be if the innovator had access to any knowledge, tools or materials desired are telling in this regard: the median answer is zero (see figure 7).

\section{INSERT PICTURES 13A-13B ABOUT HERE}

\section{INSERT FIGURE 7 ABOUT HERE}

Why innovations are kept informal. Developing solutions informally does not preclude workers from sharing their innovations. However, in contrast to the R\&D setting where innovations, whether formal or informal, are ultimately shared with superiors, sharing turns out not to be the primary concern of innovators outside of R\&D. Here the goal is to use the solution in one's own work and sharing is selective. What we observe is that people tend to share only with those people that they believe both will recognize the merits of their innovations and will not stop them from using them. Bear in mind that innovators in contrast to people who simply have an idea already have an innovation that they are benefiting from when considering whether to share with a superior. Those be- 
lieved to appreciate an innovation will typically be colleagues that the innovator interacts with on a daily basis or perhaps more distant colleagues that share a particular professional interest with the innovator. Sharing with such colleagues is essentially costless for the innovator: novel solutions are brought up in common conversation and may carry the benefit of the innovator receiving useful feedback on her innovation.

Managers, by contrast, are rarely informed about innovations, especially those managers that the workers are not in close personal contact with. This was reflected in table 5 showing that only about one in four innovators share their solutions with managers. Considering why workers tend to innovate and how they view their organization, there are several good reasons for this tendency. In part, managers are not expected to understand problems that the innovators experience in their daily work, because they do not partake in it. This corresponds very closely to why workers might choose to develop their solutions independently, rather than with the consent of their managers: managers are expected to think that workers' innovations are trivial. In the expert evaluations of soldiers' innovations, this is clearly confirmed (table 9). Two things stand out in this evaluation. For one, only a very small share of innovations are considered to be of high value; less than four percent of innovations are evaluated highly on any of the questions asked of the panel. Also, notice the difference between the evaluations on different questions: while the value of an innovation to the innovator and his/her peers is recognized to some extent, the value to the organization is generally considered to be much lower. Both tendencies reflect that soldiers' innovations are seen as trivial. In the panel evaluating the police officers' innovations, innovations are generally evaluated more meritoriously, with much higher average evaluations and larger shares of high scoring solutions. However, we observe the same tendency to evaluate the organizational value of an innovation much lower than the value to the individual officer.

In contrast to peers, managers can also explicitly instruct a worker to not use an innovation, which will be a considerable loss for the innovator, who benefits directly and personally from an innovation. Without revealing, it may be possible for an innovator to use an innovation and to get away with it, thus benefiting from the innovation. If an innovation is revealed and the innovator told to abandon it, neither the innovator nor the manager can claim to be acting in good will and ignorance. For the innovator, this defeats the purpose of having innovated in the first place - they innovate primarily to use the innovation themselves, not to have it applauded by superiors. In some cases, 
managers also understandably seem to prefer this arrangement, where they are not forced to take a stance on a particular innovation, but generally trust their subordinates to be acting in the organization's interest. In Bravo, managers would occasionally use the expression "Do it, and don't tell me how you did it" when giving orders to have particularly difficult problems solved. One officer explained that military officers know that doing their job effectively involves "constantly having one leg in jail", meaning that a certain deviance from formal procedure is considered fundamentally necessary to getting the job done (Wong \& Gerras, 2015 make a related observation in the US Army). In Metro, police officers would remark on how managers might not want to know about the innovations that people actually use, preferring instead to keep themselves out of trouble by being ignorant of them in order to maintain 'deniability' (see also Hartmann, 2014).

\section{INSERT TABLE 9 ABOUT HERE}

Revealing also carries the danger of punishment. In both organizations studied people repeatedly expressed that they were wary of not going too far and breaking rules that would get themselves or others in trouble. A particularly striking example of this is a story circulated among the police patrol officers about a colleague who had made a prototype of a more contemporary hat design. This story serves as an example of the individual risks that are at stake when frontline workers innovate in strictly regulated areas or environments of work. Within the organization, it also serves to warn others not to get similar impulses; at least, this is the effect stories like this one are described as having. The story, as it is told, is that many young police officers felt ashamed wearing a hopelessly outdated traditional uniform winter hat, also known as 'the Korean hat' (picture 14). A young patrol officer therefore bought a hat in a sporting goods store that would meet the requirements for the wide spectrum of weather conditions that police officers work in. On the front of the newly purchased hat he sewed on an official police badge that he had removed from a discarded uniform shirt in order to add a finished touch to it. When the prototype was presented to the central procurement department, the police officer was invited for a meeting with one of the administrators. She presented him to the list of violations he had committed in creating this prototype and threatened him with disciplinary punishment. According to the police officer himself, he was shocked by this reaction and stunned to 
find that about one-and-a-half years later, a new uniform hat was introduced which looked remarkably identical to the one he had been suggesting.

\section{INSERT PICTURE 14 ABOUT HERE}

Innovators thus face considerable barriers to sharing their solutions with managers: they risk being punished for having innovated, while recognizing that it is unlikely that their innovations will be appreciated. This barrier is amplified by the inconsistency that innovations might face in evaluations. Especially in Metro, a common metaphor for sharing a solution through the chain of command was that of sending off a message in bottle. You share an idea, but have very little idea where in 'the system' it might end up and who might evaluate it and by which criteria. And, if the idea is seen as valuable, it may very well be 'stolen' by superiors who claim credit for a solution. This was a common concern, especially in Country and Metro where numerous stories of such 'theft' circulated.

One particularly striking feature of the expert evaluations reflects this sense of randomness: the variability between evaluators, which for several of the questions posed to the expert panels are more than half the scale, implying that even across very few rounds of evaluation, an innovation can move from highly valuable to mediocre, or from mediocre to completely trivial. Testing for the inter-coder reliability using Fleiss' $\kappa$ for more than two raters, we observe no agreement above that attributable to chance for all but one of the questions posed to the panels (see table 9). This level of almost complete unpredictability is indicative of this inconsistency in evaluations which, if experienced by innovators in practice, is likely to drastically deter them from sharing, given that they already benefit personally and have relatively little more to gain from doing so. It is hardly surprising, given their motives for innovating in the first place, that they so often choose to keep innovations informal. 


\section{DISCUSSION AND IMPLICATIONS}

In demonstrating how innovations are informally developed and used at the working level, this study suggests that a major source of innovation and intended improvement is systematically unaccounted for. This carries implications for how innovation in organizations is thought about, studied and managed. We describe these implications after discussing the findings and methods applied in the study and the generalizability of the study.

\section{Discussion of empirical findings and methods}

The subtle and tacit characteristics of informal innovation should not blur the important roles it plays for the innovators and the organization. The sheer extent of informal innovation implies that it inevitably must produce effects for the organization, even if the exact scale of those effects is uncertain. Prior research is suggestive of this impact. Bernstein's experiment (2012) shows that making it easier for people to use what can essentially be interpreted as informal innovations increases productivity noticeably. Hollander (1965) shows that many productivity improvements come from small and easy-to-make changes in production. Mokyr describes that it is "those small improvements and adaptations to local conditions that account for most productivity gains" (1994, p. 39) and Rosenberg argues that the solutions that arise as a "by-product of productive activity" can be “individually small but cumulatively very large” (1982, p. 121).

The cumulative impact hinges, of course amongst other things, on the actual extent and different forms of informal innovation across organizational settings, which we consider a topic for further research. We can theorize about this based on our current study, but further empirical work is needed. If we follow the common logic that large public bureaucracies in general and police and military ones in particular are adverse settings for informal innovation, we would expect to find at least similar levels of informal innovation also in other organizations, provided of course that the particular settings studied here are not outliers. While this is possible, we consider it unlikely: within adverse organizational contexts, we deliberately sought out common sub-units and, having conducted our empirical studies, we can see no obvious reasons to assume that Country, Metro, Alpha and Bravo are fundamentally unlike other police and military units of their type. 
It is, however, possible and certainly a subsequent experience gives us pause for reflection. Two police districts other than Metro were given the opportunity to use our survey for internal development efforts and sent the survey by e-mail to employees in their districts. Response rates to these surveys were very low and it is quite clearly the case the respondents do not comprise a representative sample (judging from the descriptions of innovations provided, it is for instance clear that administrators are overrepresented). Nonetheless, what we learned from this material is important: innovation rates were lower and informal innovation more rare, in one police district even non-existent according to survey responses.

There are at least three possible interpretations of these very different outcomes. One is that the findings presented in this analysis are simply atypical and extreme in nature. This is possible, but also unlikely; the patterns are reasonably consistent within the three representative sub-samples where we also collected qualitative data and confidence intervals observed are far from zero. A more reasonable explanation concerns respondents' self-selection in the unrepresentative surveys: people may choose not to disclose when the recipient of the survey response is unknown or not trusted. When we introduced the survey to the representative groups of respondents, we emphasized that responses were anonymous and would not be disclosed to their organization, but only seen by the research group. Although this was also stated in the survey, the physical presence and personal presentation of the researchers prompted several of the informants to make remarks like "in that case, I'll write about my solution" and emphasize that this anonymity and presence of the researcher were necessary for honest replies. Survey respondents may simply be reluctant to reveal innovations to unfamiliar researchers that they think are acting on management's behalf. Finally, it is entirely reasonable to assume that the researchers' presence in the organizations studied influenced the salience of innovation as an idea. As described in the analysis, developing and using innovations is very much a taken-for-granted activity in the organizations studied, but having a researcher interviewing people and noticing neglected aspects of practice naturally direct attention to them. This does not imply that the researchers' presence increases innovation or informal innovation, but only that respondents become more aware that what they do can be thought of as creative and innovative.

Rather than being a reason to dismiss informal innovation as a phenomenon, we think these less well-controlled surveys carry an important methodological implication: informal innovation is not 
likely to be amenable to study using methods that do not bring the researcher very close to everyday working practices and even into personal contact with the respondents. We therefore expect that future qualitative and mixed-methods studies that successfully manage to get very close to actual working practices in organizations will reveal informal innovation to be a widely occurring phenomenon both across hierarchy and job-functions and across organizations, although the extent and forms that these activities take will obviously reflect the uniqueness of the particular setting and work that gets done. Likewise, the levels of both innovativeness and informality are likely influenced by a range of individual and organizational factors.

\section{Implications for research}

By showing the extent of informal innovation in organizations, our study raises a key challenge for innovation research, and for organization studies relating to innovation. If a considerable share of the innovations that are actually developed and used in organizations are in fact hidden even from the innovators' immediate superiors, then studies purporting to study innovation, but not accounting for the hidden dimension of it, are in fact only describing a subset of their focal phenomenon. Studies may therefore be misattributing both causes and effects of innovation and organizational functioning substantially. We may know a lot less about innovation in organizations than we purport to know.

It is not a trivial challenge, both for our methods and theorizing, to overcoming this challenge and beginning to account for the less visible sources of innovation in organizations. This study, as well as antecedent literature, suggests that the conditions and inputs that contribute to informal innovation may be very different from that of formal innovation. Organizational conditions assumed to influence formal innovation negatively (e.g. bureaucratic management techniques) or positively (e.g. separation of innovation work from everyday operations) may influence informal innovation differently, or not at all. Informal innovation also seems to be done by different and much larger groups than formal innovations and rely on inputs different from those of formal innovation. What does this mean for our assumptions about the relevance of different knowledge inputs and search, and for studies of creativity within organizations? It is also possible that informal innovations may under certain conditions spill over into formal processes, thus creating the appearance that a larger number of innovations are developed formally than is actually the case. The effects of informal innova- 
tions, similarly, may be of a different nature than formal ones. While both formal and informal innovations can have both great and small impacts and be both radical and incremental in nature, the effects of informal innovations may systematically be ascribed to other sources. Efficiency improvements from informal innovation, for instance, may be ascribed to the formal subset of innovations or various managerial initiatives, or simply be subsumed under learning curve improvements. For robust theorizing to be possible around the phenomenon of innovation, the formal-informal distinction should, at the very least, be observed.

The key challenge, then, is how to engage empirically also with those sources of innovation within the organization that are not easily captured - in the case of informal innovation because they do not follow the conventionally assumed path of being diffused through the formal hierarchy and therefore do not get recorded in standard statistics or are known by conventional survey respondents. Methodologically, we believe, there are at least two ways to deal with the challenge. We might revise our view of what we are in fact studying, when we rely on formal measures or dominant managerial accounts of innovation. Instead of thinking that this provides us with proxies for the total sum of innovation in organizations, we might recognize that they are only indicators for the formal subset of innovation. Alternatively, we can accept that there are many sources of innovation within the organization and that studying them calls for much more in-depth and mixed-method approaches, departing from the question of what innovation and innovativeness might actually mean in different organizational settings and contexts.

\section{Implications for practice}

The study not only lends weight to the proposition advanced in prior literature that non-R\&D employees can be an important source of innovation within the organization, carrying a similar implication. In important contrast to this literature, we would suggest that employees are in fact already innovating and diffusing their innovations laterally, but doing so in a way that is often hidden from management. And, more importantly, when non-R\&D employees innovate, their primary concern is likely to be to solve problems that they themselves experience - not to solve problems for others, to be rewarded by managers or to actively promote their innovations. Indeed, this paradigmatic difference between $R \& D$ and non-R\&D innovators should be front and center in the efforts to enhance innovation throughout the organization. 
If our findings are generalizable, the practical challenge for management is not building employees' capacity to innovate, but leveraging the innovative capacity that they already have, but direct at their own problems and consequently keep hidden. Recognizing that innovations are kept hidden because management is seen as unnecessary for developing and benefiting from an innovation is the first step in overcoming this challenge: many employees innovate for themselves and their private benefit, not for managerial recognition, and helping them to benefit more might be the key to leveraging their innovative capacity for greater organizational gain. Quite probably, keeping innovations hidden and relying on personal connections for diffusion lead to less benefit being derived than is individually and organizationally optimal, as suggested by Bernstein's study of increased privacy on the factory floor (2012). The same may be case for developing innovations at such low costs, which may leave innovations underdeveloped relative to their potential. Paradoxically, relying on informal innovation will obscure the problems that bring about a need for innovations, while innovators may become progressively more skilled both at innovating and at keeping their innovations hidden. In this way, informal innovation may be subject to a self-reinforcing dynamic, where more and more innovations are kept hidden.

To this end, there are several paths to pursue to better leverage employees and their ability to innovate formally.

Support innovation development. It is reasonable to think that employees will often be able to develop the innovations they need in their work using resources that are already available to them, but also that there are innovation ideas that do not get pursued, because of lack of access to tools and materials or lack of technical knowledge. Providing employees access to more, better and more varied tools, materials and knowledge is likely to help these ideas be turned into prototypes, as well as to help innovators develop solutions of higher value and quality in the short terms and, in the long term, increase the scope of innovations that they may want to engage with. Providing employees with access to 'makerspaces', for instance, would allow them to use both technical knowledge and prototyping tools not otherwise available and potentially enable the development of very valuable innovations. To date, studies have shown that even simple toolkits can dramatically improve users' abilities to develop solutions of value to themselves and others (e.g. Franke \& Piller, 2004). 
Making revealing attractive. It is important to note that employees are not only able innovate on their own initiative. It also appears that they can themselves decide whether or not to reveal their innovations - there is no pressing need for them to disclose their innovations with their superiors. To this end, we might consider whether managers could play a different role from the one they commonly have, namely as evaluators of innovations. Instead, managers might think of themselves more as supporters of solution development, testing and refinement, who provide their subordinates with the opportunity and proper conditions to experiment without the risk of sanction, such as in the 'moonshine shops' that Bernstein (2014) describe, or help innovative subordinates to get support from subject matter experts within the organization.

Diffusion infrastructures. Rather than relying on managers or the organization's formal innovation system to diffuse innovations, it might also be possible to provide employees with access to platforms enabling the horizontal diffusion of solutions across the organization, as opposed to the dual vertical processes of first evaluating solutions at progressively higher echelons, whether through 'suggestion boxes' or following the chain of command, and then implementing them top-down. The process of passing innovation upwards, we would suggest, is likely to be very inconsistent and not well-suited to sharing innovations that are grounded in working-level problems that might not be recognized elsewhere in the organization. To a certain extent, a horizontal diffusion path, where innovations are shared amongst peers who self-produce solutions (von Hippel, 2007) is already in effect in the organizations that we studied as well as in those described in prior literature, notably by Orr (1996) and Lindsay (2010). However, such horizontal diffusion appears to be dependent on the prior personal relationships of innovators. Instead, platforms inspired by those of online user communities (e.g. Jeppesen, 2008) or the Eureka system used at Xerox (Bobrow \& Whalen, 2002) might support far-reaching lateral diffusion. What is instructive about such platforms is that innovations can be shared by developers in a 'risk free' way, giving individuals the opportunity to be recognized for their creativity and receive feedback from others sharing a specific interest and problem, who in turn can benefit from those innovations. In the case of Eureka, subject matter experts who are themselves users of the informally developed innovations can provide guidance on further development. As Bobrow \& Whalen emphasize, however, the success of such platforms is contingent on recognizing the particular professional values and community dynamics shared amongst innovators and building on those social structures that are already in place. 
Relying on informal innovation processes. All the above approaches to leveraging informal innovation are based on the premise that the organization will benefit from the improved development and increased diffusion of innovation, but while this may generally be the case it is also quite possible some problems might be most efficiently solved through informal means and that efforts to manage them can be problematic (e.g. van Aken \& Weggeman, 2000). Some problems may be characterized by very high need heterogeneity across the organization or by very high information transfer costs. For such problems, formal support may only slow down problem solving at the local level and lead to the untimely implementation of standard solutions when in fact diverse solutions are called for. When this is the case, leaving employees to innovate informally for themselves may be optimal. This, however, calls for accepting informal innovation as something very different from organizational deviance and misbehavior.

\section{CONCLUSION}

Many employees serially develop innovative solutions to problems that they experience at work. And yet most of these innovations are hidden from managers, even though they are developed with the expressed intent of doing work better. While prior research has suggested that such informal innovation does happen within organizations, the findings presented here provide support both for the assertion that informal innovation is widespread (and plays a non-trivial role in organizational life) and that it is not subversive to organizational goals, but rather supportive of them (and therefore contributes to organizational performance in non-trivial ways). Informal innovation, we propose, happens for a combination of reasons. Employees frequently experience problems in their daily work that they can also solve themselves by developing innovations. Such innovations - developed and self-produced with very limited investments of time and resources - allow them to work more effectively and to do work of a higher quality. Relying on formal innovation processes, as opposed to self-developing and self-producing innovations, is unlikely to help employees solve those problems. Paradoxically, keeping innovations hidden from managers and sharing only with colleagues can be the best approach for employees intent on doing their work better. However, it may also have two problematic effects. The wider organization may never realize the benefit of innovations actually developed, thus failing to capture the efficiency benefits. Also, when employees rely on informal innovation to solve problems they experience, those problems may never be formally recognized and the gap between how work is thought about by management and how it is actually done 
may be widened, thus bringing about the need for further informal innovation in the future as more problems are unrecognized and managers in worse and worse positions to evaluate the merits of new solutions. Taken together, these propositions provide a theoretical explanations to explain why and how informal innovation occurs.

The occurrence and proposed explanations of the dynamics of informal innovation gives cause for both reflection and optimism. Reflection, we think, is needed for studies that do not take this widely occurring, but hidden, form of innovation into account, but rely instead on managerial accounts of the innovation that happens within organizations or, worse, on only formal measures of innovation. The same is the case for research seeking to attribute causal effects to innovation as an input to certain organizational processes or an effect of others: if we do not account for informal innovation in such research, we are omitting a sizable share of the actual innovation that occurs, and what, then, are we explaining? More positive, especially for managerial practice, is the potential of a vast and underutilized source of innovation within organizations that can be supported and encouraged in various ways allowing the organization to benefit, quite possibly at very low cost. There is room for much further practical and scholarly experimentation on and exploration of this phenomenon. 


\section{REFERENCES}

Ackroyd, S.

2012 "Even More Misbehavior: What Has Happened in the Last Twenty Years?" In A. Barnes and L. Taksa (eds.) Rethinking Misbehavior and Resistance in Organizations (Advances in Industrial \&amp; Labor Relations, Volume 19) Emerald Group Publishing Limited, pp.1 - 27.

Aken, J. E. and Weggeman, M. P.

2000 "Managing learning in informal innovation networks: Overcoming the Daphne-dilemma." R\&D Management. 30(2): 130-150.

Albrecth, S. L. and Goldman, P.

1985 “Men, women and informal organization in manufacturing”. Sociological focus. 18(4), 279-288

Alter, S.

2014 Theory of workarounds. Communications of the association for information systems. 34(55), p. 1041-1066.

Alvesson, M. \& Kärreman, D.

2007 "Constructing mystery: Empirical matters in theory development". Academy of Management Review. 32(4), 1265-1281.

Anonymous. 
1946 "Informal social organization in the army". American Journal of Sociology. 51(5), 365370.

Arundel, A., Casali, L. and Hollanders, H.

2015 "How European public sector agencies innovate: The use of bottom-up, policy-dependent and knowledge scanning innovation methods”. Research Policy. 44(7), 1271-1282.

Augsdorfer, P.

2005 “Bootlegging and Path Dependence”. Research Policy. 34(1) 1-11.

Axinn, W. G. and Pearce, L. D.

2006 Mixed methods data collection strategies. Cambridge university Press.

Axtell, C. M., Holman, D. J., Unsworth, K. L., Wall, T. D., Waterson, P. E. and Harrington, E.

2000 "Shopfloor innovation: Facilitating the suggestion and implementation of ideas". Journal of occupational and organizational psychology. 73(3) 265-285.

Baldwin, C. \& von Hippel, E.

2011 "Modeling a paradigm shift: From producer innovation to user and open collaborative innovation" Organization Science. 22(6): 1399-1417.

Baker, T. and Nelson, R. E.

2005 "Creating something from nothing: Resource construction through entrepreneurial bricolage". Administrative science quarterly. 50(3), 329-366. 
Barnard, C. I.

1938 The functions of the executive. Harvard University Press. Cambridge, Massachusetts.

Bensman, J. and Gerver, I.

1963 "Crime and punishment in the factory: The function of deviancy in maintaining the social system”. American Sociological Review. 28(4) 588-598.

Berliner, J. S.

1956. "The informal organization of the soviet firm". Quarterly journal of economics. 66(3), 342365.

Bernstein, E. S.

2012 "The transparency paradox: A role for privacy in organizational learning and operational control”. Administrative Science Quarterly. 57(2), 181-216.

2014 "The transparency trap". Harvard Business Review. 92(10), October, 58-66.

Bobrow, D. G. and Whalen, J.

2002 “Community knowledge sharing in practice: The Eureka story". Reflections. 4(2), 47-59.

Bogers, M., Afuah, A. and Bastian, B.

2010 "Users as innovators: A review, critique and future research directions". Journal of management. 36(4), 857-875.

Bogers, M. and Lhuillery, S. 
2006 "Measuring informal innovation: From non-R\&D to on-line knowledge production”. CEMI-REPORT-2006-09. March, 2006.

Brown, J. S. and Duguid, P.

1991 "Organizational learning and communities of practice: Toward a unified view of working, learning and innovation". Organization Science. 2(1), 40-57.

Chandler, A. D.

1977 The visible hand: The managerial revolution in American business. Harvard University Press. Cambridge, MA.

Chisholm, D.

1989 Coordination without hierarchy. Informal structures in multiorganizational systems. University of California press. Berkeley, California.

Christiansen, U., Kjærgaard, A. and Hartmann, R. K.

2012 "Working in the shadows: Understanding ERP usage as complex responsive processes of conversations in the daily practices of a special operations force." Scandinavian Journal of Management. 28(2), 173-184.

Criscuolo, P., Salter, A. and Ter Wal, A. L. J.

2013. "Going Underground: Bootlegging and individual innovative performance”. Organization Science. 25(5) 1287-1305. 
Dalton, $\mathrm{M}$.

1959 "Men who manage: Fusions of feeling and theory in administration" (2013 reprint). Transaction Publishers, New Brunswick, New Jersey.

De Jong, J. P. J.

2014 "The empirical scope of user innovation". Panteira research report, reference number H201403. Available online: http://econpapers.repec.org/paper/eimpapers/h201403.htm

De Jong, J. P. J., von Hippel, E., Gault, F., Kuusisto, J. H. and Raasch.

2015 "Market failures in the diffusion of consumer-developed innovations: Patterns in Finland" Available at SSRN: http://dx.doi.org/10.2139/ssrn.2426498

Eterno, J. A. and Silverman, E.

2012 The crime numbers game: Management by manipulation. CRC Press. New York, NY.

Firey, W.

1948 "Informal organization and the theory of the schism". American Sociological Review. 13(1), 15-24.

Fosfuri, A. and Rønde, T.

2009 "Leveraring resistance to change and the skunk works model of innovation". Journal of economic behavior \& organization. 72(1) 274-289. 
Franke, N. and Shah, S.

2003 "How communities support innovative activities: An exploration of assistance and sharing among end-users". Research Policy. 32(1) 157-178.

Franke, N. and Piller, F.

2004 Value creation by toolkits for user innovation and design: The case of the watch market. Journal of Product Innovation Management. 21(6) 401-415.

Franke, N. and von Hippel, E.

2002 Satisfying heterogenous user needs via toolkits: the case of Apache security software. Research Policy. 32(7), 1199-1215.

Geertz, C.

1973 "Thick Description: Toward an Interpretive Theory of Culture". In The Interpretation of Cultures: Selected Essays. New York: Basic Books, 1973. 3-30.

Gulati, R. and Puranam, P.

2009 "Renewal through reorganization: The value of inconsistencies between formal and informal organization”. Organization Science. 20(2), 422-440.

Hartmann, M. R. K.

2014 "In the gray zone: With police in making space for creativity". Copenhagen Business School Ph.D.-series nr. 39.2014. Frederiksberg, Denmark. 
Hienerth, C.

2006 "The commercialization of user innovations: the development of the rodeo kayaking industry". R\&D management. 36(3), 273-294.

Hienerth, C., von Hippel E. and Berg Jensen M.

2014 "User community vs. producer innovation development efficiency: A first empirical study”. Research Policy. 43(1), 190-201.

Hunt, J.

1984 "The development of rapport through the negotiation of gender in fieldwork among police”. Human organization. 43(4), 283-296.

Hunt, J.

1985 "Police accounts of normal force". Journal of contemporary ethnography. 13(4), 315-341.

Hunt, J. and Manning, P. K.

1991 "The social context of police lying”. Symbolic interaction. 14(1), 51-70.

Hyysalo, S. and Usenyuk, S.

2015 “The user-dominated technology era: Dynamics of dispersed peer-innovation”. Research Policy. 44(3), 560-576.

Jensen, M. B., Johnson, B., Lorenz, E. and Lundvall, B. A.

2007 "Forms of knowledge and modes of innovation". Research Policy. 36(5), 680-693. 
Jeppesen, L. B.

2008 "User toolkits for innovation: Consumers support each other". Journal of product innovation management. 22(4), 347-362.

Kesting, P. and Ulhøi, J. P.

2010 "Employee-driven innovation: Extending the license to foster innovation". Management decision. 48(1), 65-84.

Knight, K. E.

1967 "A descriptive model of the intrafirm innovation process". Journal of Business. 40(4), 478496.

Kollars, N.

2012 "By the seat of their pants. Military technological adaptation in War". Ph.D. thesis. Ohio State University.

Kreiner, K. and Schultz, M.

1993 "Informal collaboration in R\&D. The transformation of networks across organizations". Organization studies. 14(2), 189-209.

Kusterer, K. C.

1978 Know-how on the job: The important working knowledge of "unskilled" workers. Westview Press. 
Lave, J. \& Wenger, E.

1991 Situated learning: Legitimate peripheral participation. Cambridge University Press. Cambridge, UK.

Lee, Y.-N. \& Walsh, J. P.

2016 "Inventing while you work: Knowledge, non-R\&D learning and innovation". Research Policy. 45(1) 345-359.

Lettl, C.

2007 "User involvement competence for radical innovation". Journal of Engineering and Technology Management. 24(1), 53-75.

Levi-Strauss, C.

1966 The savage mind. London, Weidenfeld \& Nicolson.

Lindsay, J.

2010 "War upon the map: User innovation in American military software". Technology and culture. 51(3), 619-651.

Lüthje, C., Herstatt, C. and von Hippel, E.

2005 “User-innovators and 'local information': The case of mountain biking". Research Policy. 34(6) $951-965$. 
Mars, G.

1982 Cheats at work: An Anthropology of workplace crime. George Allen \& Unwin, London, UK.

Maxwell, J.

1992 "Understanding and validity in qualitative research". Harvard Educational Review. 62(3), 279-301.

Merton, R. K.

1940 "Bureaucratic structure and personality". Social Forces. 18(May), 560-568.

Miller, P. and Wedell-Wedellsborg, T.

2013 “The case for stealth innovation”. Harvard Business Review. 91(3), 90-97.

Morey, N. C. and Luthans, F.

1991. "The use of dyadic alliances in informal organization: An ethnographic study". Human Relations. 44(6), 597-618.

Morison, E.

1966 "Gunfire at sea: A case study of innovation”. In: Morison, E. Men, machines and modern times. MIT Press. Cambridge, MA, USA.

Nadler, D. A. and Tushman, M. L.

1980. “A model for diagnozing organizational behavior”. Organizational dynamics. 9(2), 35-51. 
Neyland, D.

2008 Organizational ethnography. Sage Publications. Thousand Oaks, California.

Orr, J. E.

1996 Talking about machines: An ethnography of a modern job. Cornell university press: Ithaca, NY, USA.

Pina e Cunha, M., Rego, A., Oliveira, P., Rosado, P. and Habib, N.

2014 "Product innovation in resource-poor environments: Three research Streams". Journal of product innovation management. 31(1), 202-210.

Rich, B. R. and Janos, L.

1996 Skunk works: A personal memoir of my years at Lockheed.

Riggs W. and von Hippel, E.

1994 "Incentives to innovate and the sources of innovation: the case of scientific instruments". Research Policy. 23(4), 459-469.

Rizova, P. S.

2007 The Secret of Success: The Double Helix of Formal and Informal Structures in an R\&D Laboratory. Stanford University Press. Stanford, California.

Roethslisberger, E. J. \& Dickson, W. J. 
1939 Management and the worker: an account of a research program conducted by the General Electric company, Hawthorne works, Chicago. Harvard University Press. Cambridge, Massachusetts.

Roy, D.

1952 "Quota Restriction and goldbricking in a machine shop". American Journal of Sociology. $57(5), 427-442$.

Schon, D. A.

1967 Technology and change: The new Heraclitus. Delacorte Press. New York, New York.

Selznick, P.

1948 "Foundations of the theory of organizations". American sociological review. 13(1), 25-35.

Shapiro-Perl, N.

1979 "The piece-rate: Class struggle on the shop floor. Evidence from the costume jewelry industry in Providence, Rhode Island". In: A. Zimbalist (ed.) Case studies in the labor process. New York: Monthly Review, 277-.298

Svensson, P. \& Hartmann, R. K. H.

2015 "Policies to promote user innovation: Evidence from Swedish hospitals on the effects of clinicians' access to makerspaces". Paper available at SSRN:

http://papers.ssrn.com/sol3/papers.cfm?abstract id=2701983 
Tushman, M. J. and O'Reilly, C. A.

1996 “Ambidextrous organizations: Managing evolutionary and revolutionary change". California Management Review. 38(4), 8-30.

Van Aken, J. E. and Weggeman, M. P.

2000 "Managing learning in informal innovation networks: Overcoming the Daphen dilemma". R\&D Management. 30(2), 139-150.

Van Maanen, J.

2011 Tales of the field: On writing ethnography. University of Chicago press. Chicago, Illinois.

von Hippel, E.

1976 "The dominant role of users in the scientific instrument innovation process". Research Policy 5(3), 212-239.

1986 "Lead Users: A source of novel product concepts". Management Science. 32(7), 791-805.

1987 “Cooperation between rivals: Informal know-how trading”. Research Policy. 16, 291-302.

1988. The sources of innovation. MIT Press. Cambridge, Massachusetts.

1994 “"Sticky information" and the locus of problem solving: Implications for innovation". Management Science. 40(4), 429-439.

2005 Democratizing innovation. MIT Press. Cambridge, Massachusetts.

2007 "Horizontal innovation networks - by and for users". Industrial and corporate change. 16(2), 293-315.

von Hippel, E., de Jong, J. P. J. and Flowers, S. 
2012 "Comparing business and household sector innovation in consumer products: Findings from a representative survey in the United Kingdom”. Management Science. 58(9), 1669-1681.

von Hippel E., Franke, N. and Prugl, R.

2009 "Pyramiding: Efficient search for rare subjects". Research Policy. 38(9), 1397-1406.

von Hippel, E. and von Krogh, G.

2003 "Open source software and the "private-collective" innovation model: Issues for organization science”. Organization Science. 14(2), 209-223.

Weber, M.

1946 Bureaucracy. In Fischer, F. and Sirianna, C. (eds) 1994. Critical Studies in Organization and Bureaucracy. Temple University Press. Philadelphia, PA.

Weisburd, D. and Braga, A. A.

2006 Police innovation: Contrasting perspectives. Cambridge University Press. Cambrige, UK.

Wong, L. and Gerras, S. J.

2015 Lying to ourselves: Dishonesty in the Army profession. Strategic studies institute and U. S. Army War College Press. Carlisle, Pennsylvania.

Zurcher, L. A.

1965 The sailor aboard ship: A study of role behavior in a total institution. Social Forces. 43(3), $389-400$. 
TABLES, FIGURES AND PICTURES

(presented chronologically) 


\begin{tabular}{|c|c|c|}
\hline Number & Name & Description of solution \\
\hline 1 & $\begin{array}{l}\text { Magazine pouch } \\
\text { (picture 1) }\end{array}$ & $\begin{array}{l}\text { A very thin, low-profile magazine pouch that is also very short, } \\
\text { leaving much of the magazine exposed. While soldiers often } \\
\text { keep magazines in pouches on their chest, many carry a maga- } \\
\text { zine pouch or two on their hip. These are the ones from which } \\
\text { magazines are drawn when reloading their rifle. This pouch is } \\
\text { both very low-profile (so that it does not protrude very far from } \\
\text { the soldier's body) and not very high, so that there is a lot of } \\
\text { the magazine to grab. Also, the inside of the pouch is lined } \\
\text { with hypalon (a material used in the construction of inflatable } \\
\text { boats) that 'grips' the magazine to prevent it falling out of the } \\
\text { pouch. At the same time, the elastic ensures that the magazine } \\
\text { will not fall out as the soldier moves, runs or throws himself to } \\
\text { the ground. This makes grapping the magazine easier and re- } \\
\text { loading faster. }\end{array}$ \\
\hline
\end{tabular}

2 Torque socket for machine gun maintenance

(picture 2)

Vehicle-mounted pumping antenna (picture 3)
The heavy machine gun used by the Danish Army is the Browning M2 50 caliber machine gun. At the rear of this gun, between the spade handles and below the butterfly trigger, is a rear buffer. When the machine gun is taken in for maintenance by the company-level mechanic, this buffer has to be tightened. The torque socket allows this buffer to be tightened using a torque wrench.

An armored infantry company consists of three infantry platoons (two armored ones in infantry fighting vehicles of the type CV90 and one mechanized one in armored personnel carriers of the type M113) and a command element. The command element is led by the company's first sergeant, who is mounted in an armored personnel carrier. His role is typically to lead the command element (a platoon-sized unit), including its support units (a logistic section and a mechanic section) The command element maintains radio communication

\section{Description of problem}

Standard magazine pouches have a cover going over the magazine to ensure that it does not fall out. However, this requires many more operations and movements before a magazine can be extracted. Also, the standard pouches are made to hold two magazines, so they are wider and bulky.

A new manual was recently issued, changing the standard maintenance procedure for the heavy machine gun. With the prior manual, the buffer had to be adjusted using visual cues: one complete thread around the buffer had to be visible and the ridge in the center of the buffer aligned to vertical. This adjustment is done with an issued tool that fits into the ridge of the buffer. According to the new manual, the buffer has to be tightened to a certain torque (or 'moment'), i.e. to a certain hardness as measured using the unit newton meter (Nm). However, there is no tool issued by the military that allows the mechanics to do this, making it impossible to comply with the new manual. The torque socket solves this problem. by fitting one end to a torque wrench and the other into the ridge of the buffer.

Having the pumping antenna mounted on the side of the armored personnel vehicle makes set-up considerably faster than it would be using the tripod. The tripod has to be stored inside the vehicle. This which means that the gunner has to climb down the vehicle, around the back of the vehicle, wait for the latch to open (the driver does this), unpack and pull out the tripod and only then begin to assemble it. With this solution, setup only requires the gunner to go to the side of the vehicle and flip up the pumping. 


\section{Table 1 (continued)}

between the company's units and between the company and the battalion, if these cannot reach each other using their vehiclemounted radios. To do so, the first sergeant's vehicle has a 'pumping antenna' that can be used to raise the radio's antenna $30+$ feet in the air and thus get improving transmission and reception of signals.

This pumping antenna is usually mounted on a tripod that must be set up next to the vehicle.

Here, the gunner on the first sergeant's vehicle has developed a way to mount the pumping antenna directly on the side of the the vehicle. This removes the need for setting up a tripod. When the vehicle is moving, the pumping antenna is collapsed to its minimal length and placed horizontally above the vehicle's track guard, where it is secured. When it stops, the pumping antenna is raised to a vertical position and secured. Then. the radio antenna is placed in the socket on top of the pumping antenna and the pumping antenna raised

The cannon on an infantry fighting vehicle is a very technical weapon that is somewhat complicated to operate. As a consequence, instructing people in it its use is also complicated. This not only relates to the mechanics of the weapon and how it functions. It also relates to how the soldier operates it. Instruction is all the more complicated given the conditions under which it normally has to happen: within the confined space of a turret, where there is limited room to move around and limited opportunity for an instructor supervise how the student oper-

ates. Here, the cannon of the infantry fighting has been mounted on a wheeled base and part of the weapon cut away to reveal how the weapon works when firing. The base allows for the cannon to be turned at various angles to clearly demonstrate how it functions. This allows instructors to explain the functioning of the weapon, to demonstrate the use of it in an open space, to let students try to operate the weapon in a less confined space, and to teach how to repair malfunctions much more visibly that than is otherwise the case. This improves the instruction in the use and handling of the weapon, before crews progress to working with the weapon inside the turret. antenna. Similarly, when the antenna has to be taken down, there is no packing required, because it is merely flipped down and secured. This means that the first sergeant is on net more quickly and better able to relay communications within and between units

It is very difficult to meaningfully and clearly instruct in the use of the cannon, when it is mounted in the turret. Mounting the cannon on a base outside of the vehicle greatly improves instruction. 


\section{Table 1 (continued)}

5 'Throwing rope' with explosives for IED clearance (not pictured)
When soldiers encounter IEDs, the standard operation procedure is normally to form a cordon and then disarm it. This procedure can be very time-consuming, because cordons have to be placed at in a perimeter 600 yards around the IED and explosive demolition teams called in to do the actual disarming. When a particular route has many IEDs placed on it, it can be all but impossible for a patrol to retain momentum and to avoid enemy forces setting up ambushes.

A group of soldiers developed an alternative approach to clearing a path of IEDs. This approach was used only when it was seen as necessary to move very quickly and when speed has to be prioritized, such as when rapidly moving towards an objective. Their solution involves tying small lumps of plastic explosives to a long detonating cord. This cord is used as a 'throwing rope': it is thrown across the length of the area that needs to be opened up and the cord and its explosives detonated. This chain of explosions detonates any IEDs buried in the ground underneath the rope, so that it can be crossed (relatively) safely by a patrol or vehicle.

The field manual for platoon and squad level operations states that soldiers should wear infrared markings when operating in the dark, allowing them to easily see and identify each other as friendly forces when looking through their night vision devices. However, this does not solve the problem of identifying leader within the unit in the dark: soldiers will often have to find the leaders and leaders have to find other leaders to coordinate and this is not easy when everyone is marked the same way (night vision goggles are not good at discerning facial features).

Here, a platoon has devised a way to tell soldiers marked with infrared light apart. Instead of all soldiers having an exposed infrared chemlight attached to their helmet. this platoon keeps the chemlights in the bags they are delivered in. These chemlights are then broken while in the bag and small holes cut in the bag: for shooters, a single hole is cut; for squad leaders, three; for the platoon sergeant, four; and for the platoon leader, five (this corresponds to the call signs attached to the respective functions).
The throwing rope makes it possible to clear an IED-mined area much more rapidly, albeit also less safely. than the standard operating procedure. When an operation calls for moving quickly, such as to retain an element of surprise, to support units in need or to avoid an ambush, this can be advantageous.

The solution makes identification of specific person considerably easier, which speeds up coordination work and. Ultimately, execution of operations. It also improves soldiers' situational awareness, because they can more easily tell who is where and what is happening, when they have an idea of where their leaders are.

Also, as a side effect, keeping the chemlights in their bags, rather than fully exposing them, reduces the amount of bright infrared light that soldiers will see in their night vision devices. Too much of such light can create glare in the device and feel blinding. This is especially the case when the night vision device is turned up to its highest level of light amplification (this is how the night vision device works: it amplifies the ambient light) 


\section{Table 1 (continued)}

Street guide (picture 8a, 8b, 8c)
Police officers will frequently have to enter stairwells in residence buildings when responding to emergency calls. This may be the case when they receive reports of domestic disturbances or violence or threats of violence, or need to conduct a search. Here, officers have made a lock opener from a piece hard plastic cut out of a soda bottle. This tool is similar to that used by burglars and allows them to open a locked door by sliding the plastic between the door and the doorframe and manipulating the latch. This exploits the fact that many buildings in Metro's jurisdiction do not have modern locks, but old ones that can be opened using this technique.

The plastic tool is flat and fits easily in the thigh pocket of an officer's uniform.

Police officers responding to e.g. traffic accidents may occasionally need to break a car window in order to reach a passenger trapped inside.

Here, an officer has taken a window breaker typically used in busses or trains and modified it to make it smaller and more convenient to carry on a daily basis.

Police officers working in the front desk of the police station are the ones receiving most of the reports of violent crimes. Here, a police officer will receive the report and interview the victim. After the interview, the victim may be given a flyer for one of the various ways to get support (e.g. psychological therapy, counselling, etc.).

Here, a police officer has set-up an internet-based forum for victims of violent crimes and rape, where victims can chat with one another, share their experiences and receive advice and support. This provides an alternative way for victims to receive support.

When on patrol, officers receive calls over the radio to respond to issues on a given address. If they do not know the address, they will type it into a GPS or look it up in a map book.

Here, a group of officers have created an A5 binder with an index of all the streets in Metro's jurisdiction, noting for all
Gaining access to a stairwell requires the officers to enter through a door that is typically locked. Having to respond to an emergency call, police officers will often want to enter without relying on someone in an apartment to open the door for them. This will require them to either break down the door, which is clearly undesirable, or contacting a locksmith to open it, which will take long time.

Police officers are not issued a tool that allows them to break windows, even though their job sometimes requires them to do so, for instance in connection with traffic accidents or when needing to enter a building. They are issued a multitool, but this does not have a windowbreaking feature.

Victims of violent crimes often come to the police station to report the crime. When an officer's girlfriend was the victim of a robbery, he became aware of two problems of this process. For one, it became apparent that the standard way police officers handle victims reporting violent crimes is quite harsh for people having just experienced a crime. Second, it became apparent that there was no peer-to-peer support program for victims, but only varieties of ways to receive expert support, with peer-to-peer support being exactly what his girlfriend felt she needed.

Many of the police officers working in Metro are not from the city, but move there from other places in the country. They can therefore have a difficult time finding their way around the many small road and side-roads of in Metro's jurisdiction, many of which are unidirectional. This can make it difficult 
Table 1 (continued)

which larger the larger streets they are close to. This means that when a patrol car receives a call to go somewhere, the officer who is not driving will look up the street they are going to and can then tell the driving officer which major road to drive towards. Then, when the car is driving in the right direction, the specific location can be looked up on the relevant maps. This allows the patrol car to respond more quickly to calls (response time is measured in minutes, so spending two minutes typing an address into a GPS unit or finding the specific location of a small street is not considered time well spent). Even after the implementation of GPS units in the police vehicles, this solution continues to be used, for two reasons. For one, it is faster than a GPS. Second, GPS units do not allow for driving against traffic on one-way streets, which police cars are allowed to do when responding (which also can save time).

The street guide binder also contains maps of the layout of various locations that officers will typically be called to, such as train stations, making it easier to arrive in the right place.

11 Undercover equipment belt (picture 9)
Police officers will occasionally be assigned to plainclothes tasks, where they wear civilian clothes rather than uniforms. This might be the case for surveillance tasks, patrolling, etc. While doing so, officers will still need to carry their equipment. Typically, equipment is carried in a standard issued belt which is carries visibly on the officer's hips. However, the belt is not intended for plainclothes assignments, but for uniformed work where concealment is not an issue. As such, the issued belt is easily visible beneath the officer's civilian clothes, mak ing it difficult for police officers to be inconspicuous during plainclothes work. No belt is issued for plainclothes assignments.

Here, a police officer has bought an oversized elastic belt and modified it to fit his equipment. This modified belt can be carried around the stomach, rather than the hips, allowing it to be covered by clothing while still having the equipment readily accessible. for them to respond quickly to emergency calls

The issued belt makes it impossible to carry the officer's equipment (pepper spray, pistol, handcuffs, baton, etc.) concealed beneath a jacket or, during summer, a t-shirt. This will almost always make the officer readily identifiable as police, compromising the idea of doing an assignment in plainclothes. Moreover, the issued belt has the baton placed on the officer's back. When driving, this causes the officer to sit on baton, which can cause pressure on the sciatica and be very painful. 
When conducting searches, police officers will sometimes need to break in doors in order to gain access to a building. The occupants of a building may have locked or even barricaded the doors to prevent this.

Here, a police officer together with his father (who is a smith) has designed a battering ram with several improved features over the standard issue. For one, it can be operated by several officers at the same time, allowing more force to be applied to the door breaking effort. Second, the tip of the ram can be

switched out depending on what is being battered. In one case, officers experienced that the outside of a door to a gang building was barricaded with plastic crates that were almost impossible to ram through with an ordinary tip (because the crates had large holes in them, it was difficult to hit them powerfully), but easy to break with a tip with a larger striking surface.
The officers have access to a standard issue battering ram, bu not in sufficient numbers for their needs - there is only one available per station. Moreover, this issued ram cannot easily be used by two people, meaning that breaking through doors is harder and slower, which is not desirable. Also, the tip of the ram is not suited to all the possible obstructions that police of ficers encounter. 
Picture 1: Magazine pouch

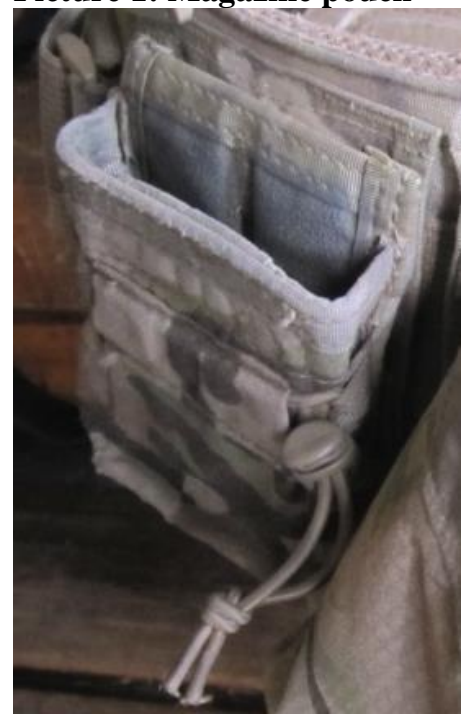


Picture 2: Torque socket for machine gun maintenance

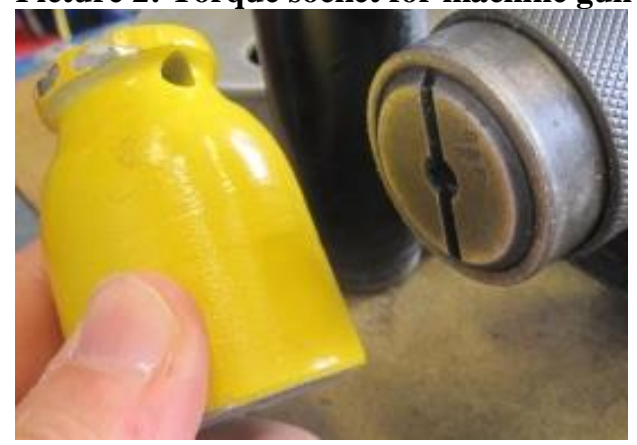


Picture 3: Vehicle mounted pumping antenna

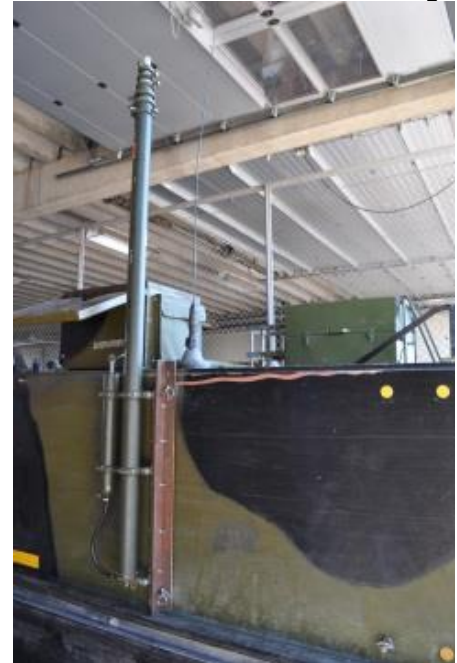


Picture 4: IFV gun display

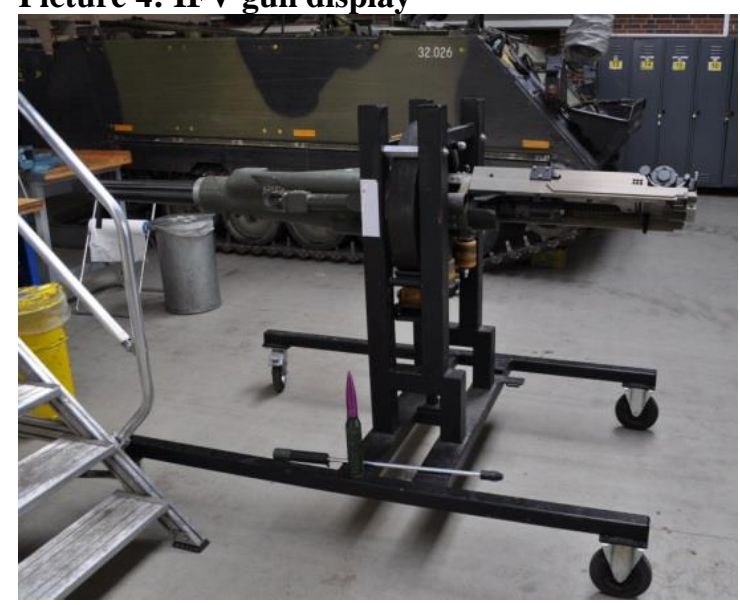


Picture 5: Infrared marking of individuals

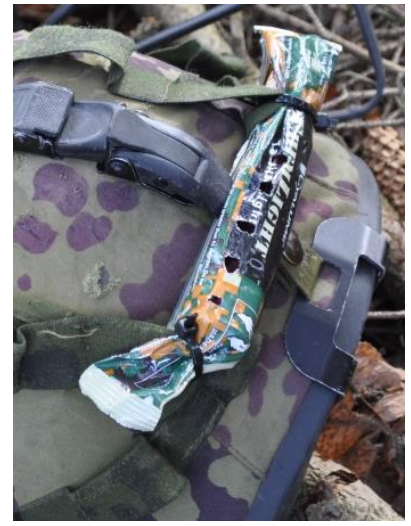


Picture 6: Lock opener

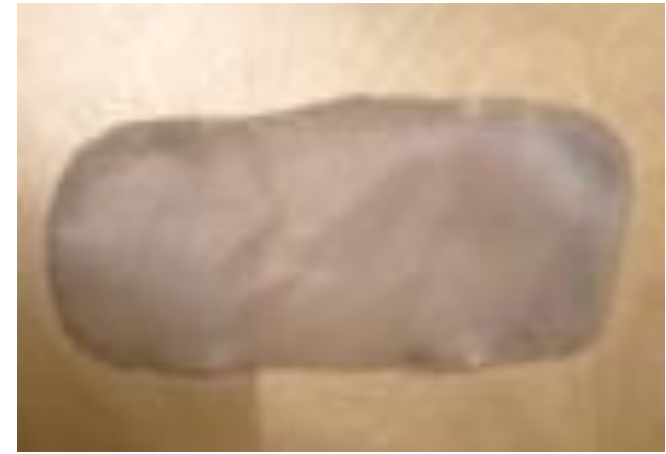


Picture 7: Window breaker

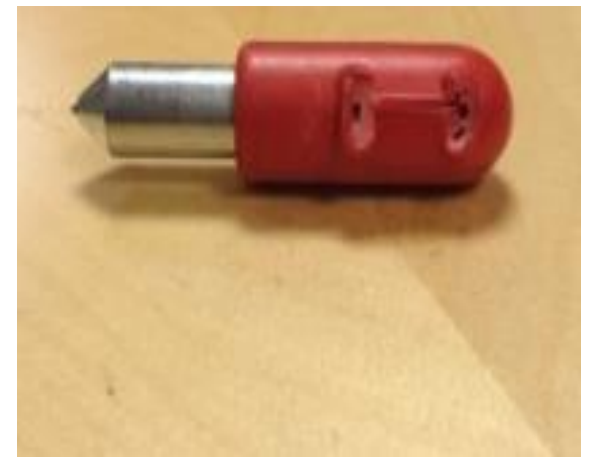




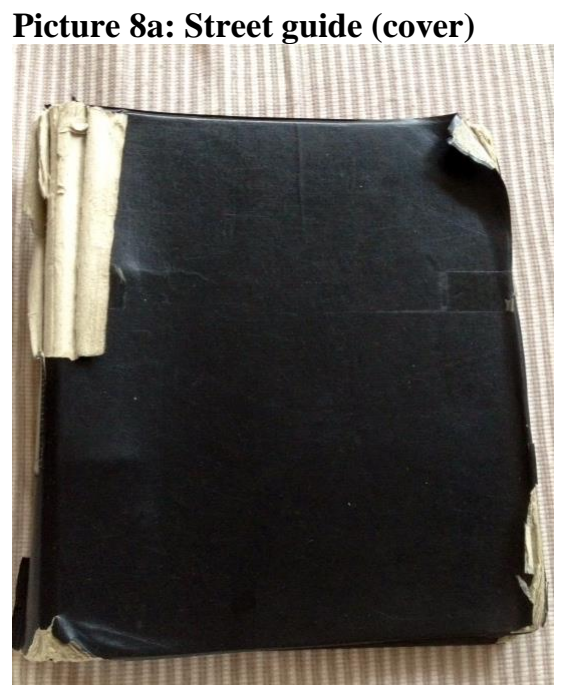

Picture 8b: Street guide (directory)

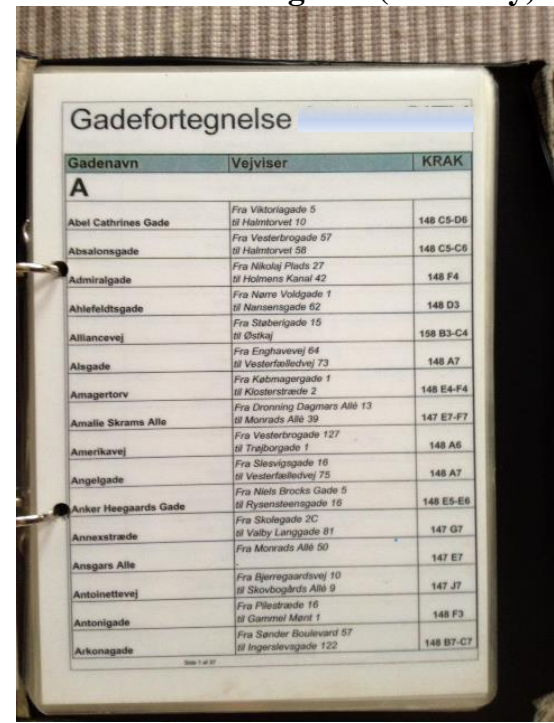

Picture 8c: Street guide (area map)

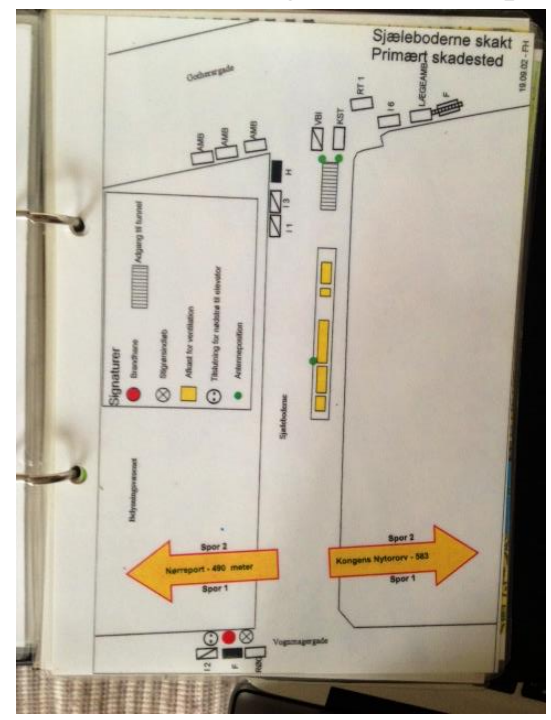




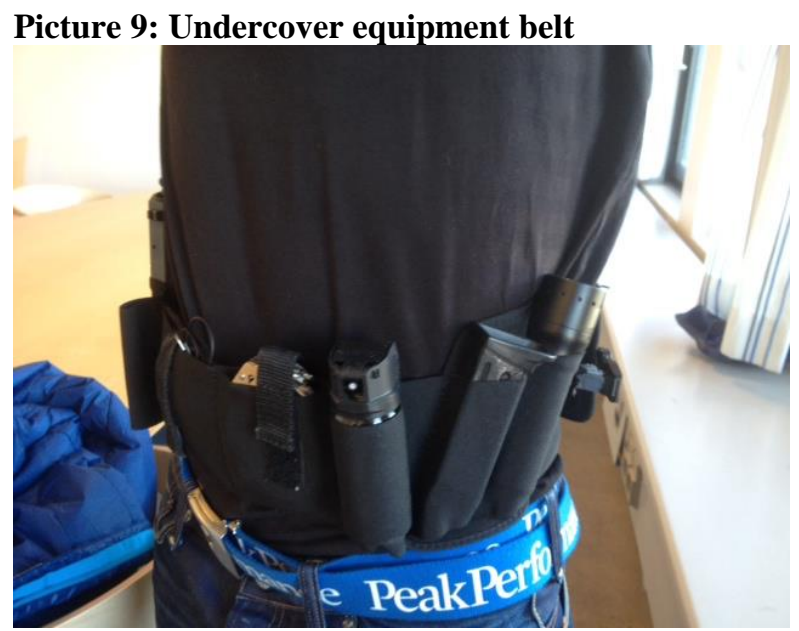


Picture 10: Battering ram

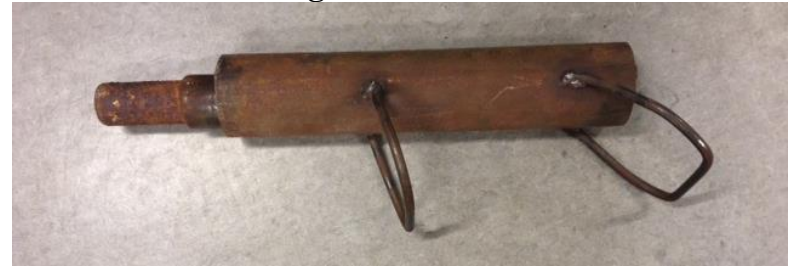


Figure 1. Classification of innovators.

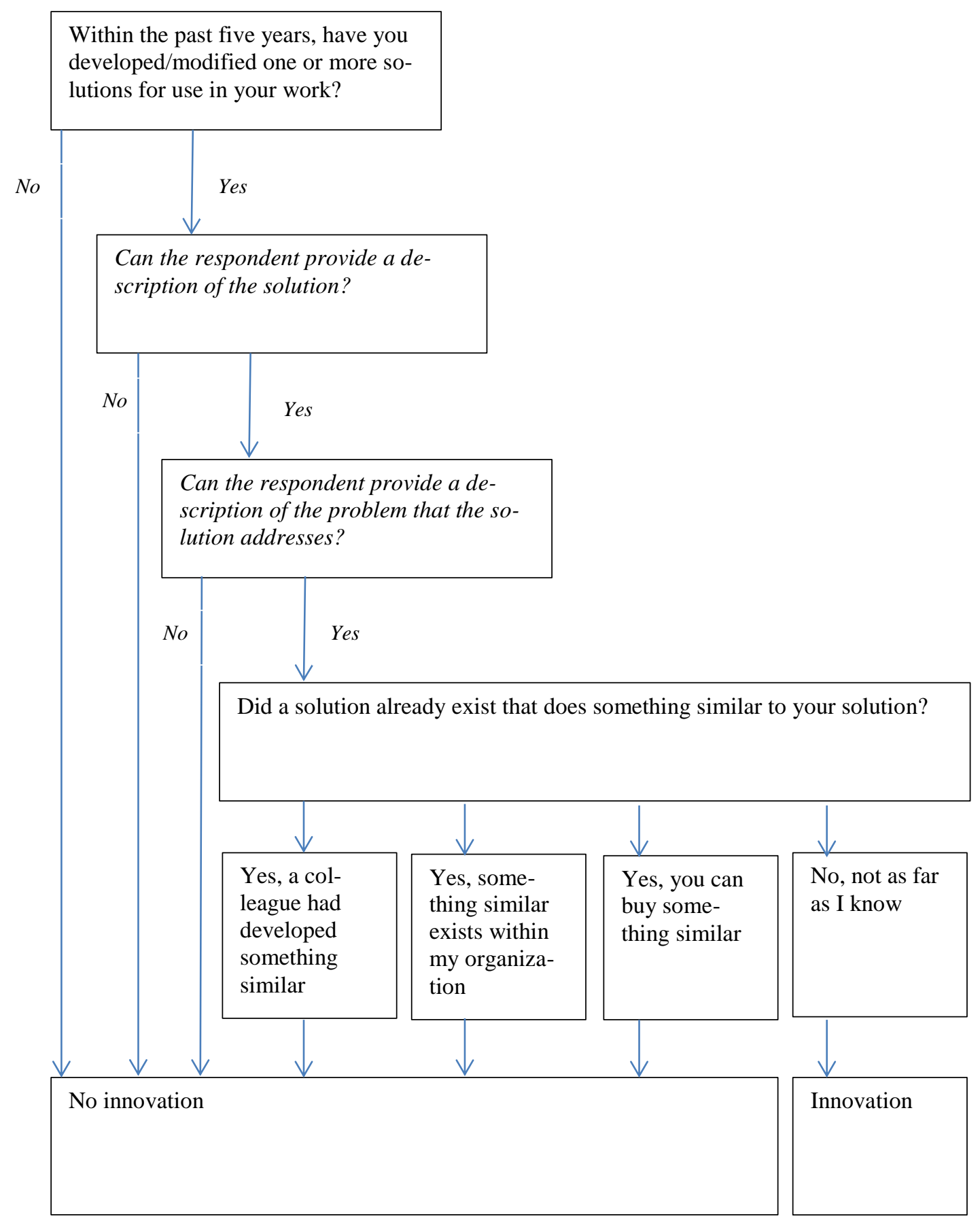


Table 2: Share of innovators in each organization

\begin{tabular}{lccccccccc}
\hline & \multicolumn{2}{c}{ Metro } & \multicolumn{2}{c}{ Alpha } & \multicolumn{2}{c}{ Bravo } & \multicolumn{2}{c}{ Total } \\
& $\#$ & $\%$ & $\#$ & $\%$ & $\#$ & $\%$ & $\#$ & $\%$ \\
\hline Respondents & 66 & 100 & 70 & 100 & 69 & 100 & 205 & 100 \\
$\begin{array}{l}\text { Have developed/modified } \\
\text { solutions }\end{array}$ & 52 & 78.8 & 62 & 88.6 & 63 & 91.3 & 177 & 86.3 \\
Have made innovations & 22 & 33.3 & 23 & 32.9 & 28 & 40.6 & 73 & 35.6 \\
\hline
\end{tabular}


Figure 2: Number of solutions/modifications developed by each innovator $(n=73)$

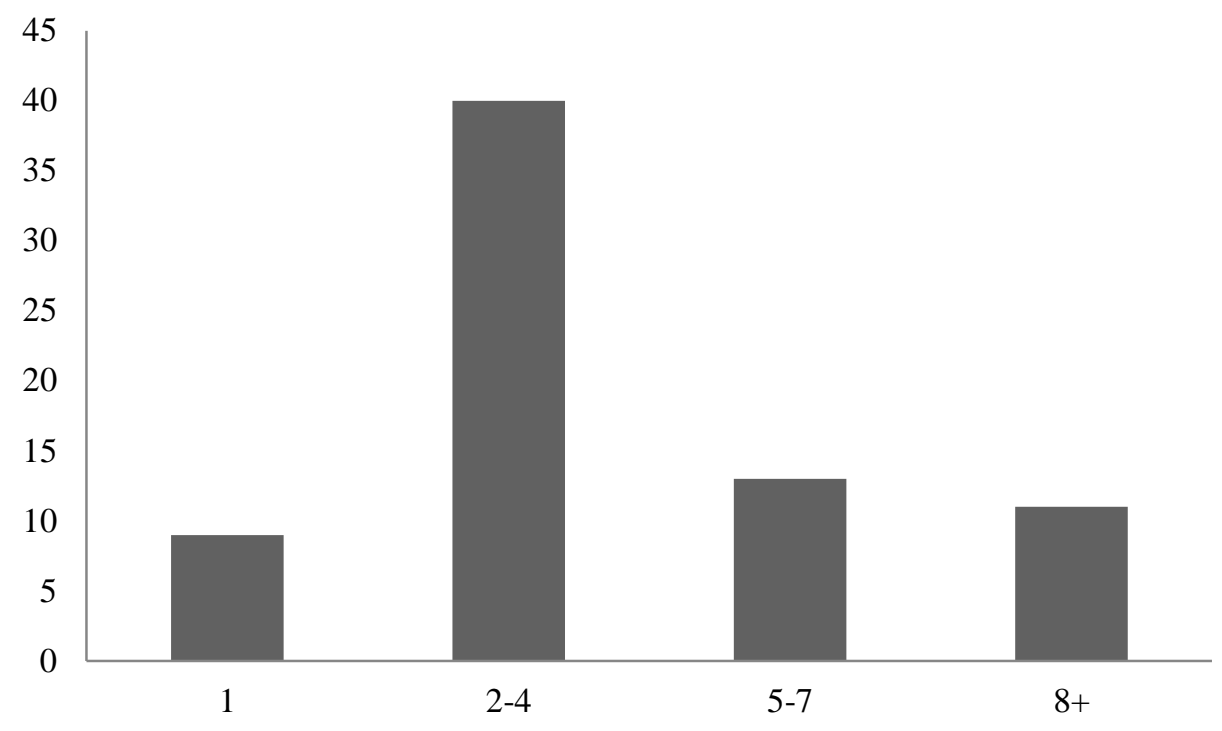


Table 3: Types of innovations developed

\begin{tabular}{lcccccccc}
\hline & \multicolumn{2}{c}{ Metro } & \multicolumn{2}{c}{ Alpha } & \multicolumn{2}{c}{ Bravo } & \multicolumn{2}{c}{ Total } \\
& $\#$ & $\%$ & $\#$ & $\%$ & $\#$ & $\%$ & $\#$ & \\
\hline Gear and equipment & 12 & 54.5 & 18 & 78.3 & 23 & 82.1 & 53 & 72.6 \\
Clothing & 5 & 22.7 & 6 & 26.1 & 10 & 35.7 & 21 & 28.8 \\
Techniques & 4 & 18.2 & 7 & 30.4 & 7 & 25.0 & 18 & 24.7 \\
Vehicles & 1 & 4.5 & 6 & 26.1 & 11 & 39.3 & 18 & 24.7 \\
Weapons & 2 & 9.1 & 4 & 17.4 & 9 & 32.1 & 15 & 20.5 \\
Training & 2 & 9.1 & 4 & 17.4 & 6 & 21.4 & 12 & 16.4 \\
Administrative processes & 8 & 36.4 & 2 & 8.7 & 1 & 3.6 & 11 & 15.1 \\
IT and technology & 3 & 13.6 & 2 & 8.7 & 0 & 0.0 & 5 & 6.8 \\
Other & 2 & 9.1 & 1 & 4.3 & 2 & 7.1 & 5 & 6.8 \\
\hline $\mathrm{n}$ & 22 & 100.0 & 23 & 100.0 & 28 & 100.0 & 73 & 100.0 \\
\hline
\end{tabular}


Picture 11: Standard police belt

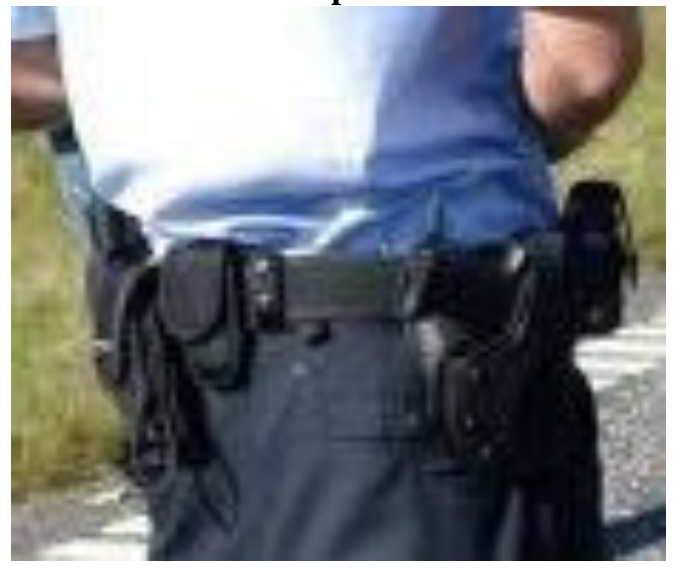


Table 4: Motives for developing innovations

\begin{tabular}{|c|c|c|c|c|c|c|c|c|}
\hline \multirow[t]{2}{*}{ Motive for developing innovation } & \multicolumn{2}{|c|}{ Metro } & \multicolumn{2}{|c|}{ Alpha } & \multicolumn{2}{|c|}{ Bravo } & \multicolumn{2}{|c|}{ Total } \\
\hline & \# & $\%$ & \# & $\%$ & \# & $\%$ & \# & $\%$ \\
\hline To improve effectiveness & 12 & 54.5 & 12 & 52.2 & 22 & 78.6 & 46 & 63.0 \\
\hline To improve quality of work done & 11 & 50.0 & 14 & 60.9 & 19 & 67.9 & 44 & 60.3 \\
\hline $\begin{array}{l}\text { Because it was 'nice' (i.e. personal conven- } \\
\text { ience) }\end{array}$ & 9 & 40.9 & 14 & 60.9 & 19 & 67.9 & 42 & 57.5 \\
\hline $\begin{array}{l}\text { To compensate for problems with formal } \\
\text { solutions }\end{array}$ & 8 & 36.4 & 8 & 34.8 & 15 & 53.6 & 31 & 42.5 \\
\hline To improve safety in work & 7 & 31.8 & 5 & 21.7 & 8 & 28.6 & 20 & 27.4 \\
\hline To fix something that was broken & 2 & 9.1 & 5 & 21.7 & 5 & 17.9 & 12 & 16.4 \\
\hline $\begin{array}{l}\text { To solve new problems encountered in } \\
\text { work }\end{array}$ & 2 & 9.1 & 4 & 17.4 & 4 & 14.3 & 10 & 13.7 \\
\hline $\begin{array}{l}\text { To adapt existing solutions to new condi- } \\
\text { tions }\end{array}$ & 3 & 13.6 & 3 & 13.0 & 3 & 10.7 & 9 & 12.3 \\
\hline $\begin{array}{l}\text { To make an existing thing useful for new } \\
\text { purpose }\end{array}$ & 1 & 4.5 & 0 & 0.0 & 3 & 10.7 & 4 & 5.5 \\
\hline To follow formal rules & 1 & 4.5 & 0 & 0.0 & 1 & 3.6 & 2 & 2.7 \\
\hline Other & 1 & 4.5 & 1 & 4.3 & 1 & 3.6 & 3 & 4.1 \\
\hline $\mathrm{N}$ & 22 & 100.0 & 23 & 100.0 & 28 & 100.0 & 73 & 100.0 \\
\hline
\end{tabular}


Table 5: Innovators' evaluations of importance and value to others

\begin{tabular}{lcccc}
\hline & Metro & Alpha & Bravo & Total \\
\hline Importance of innovation & & & & \\
Mean & 4.3 & 4.5 & 5.0 & 1.6 \\
s.d. & 1.8 & 1.9 & 1.5 & $27(37.0 \%)$ \\
$>5$ & $7(31.8 \%)$ & $8(34.8 \%)$ & $12(42.9 \%)$ & 4.4 \\
Value to others & & & 5.1 & 1.9 \\
Mean & 4.3. & 3.8 & 1.3 & $23(32.4 \%)$ \\
s.d. & 1.8 & 2.4 & $10(35.7 \%)$ & $2(33.3 \%)$ \\
$>5$ & $6(27.3 \%)$ & & & \\
\hline
\end{tabular}


Picture 12: Door holder

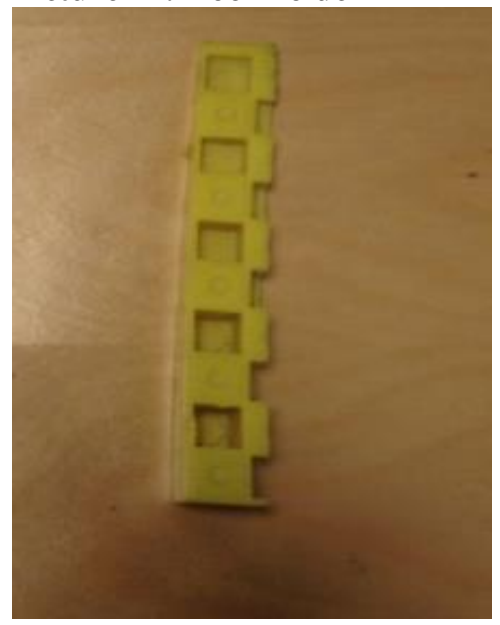


Figure 3. Classification of informal innovators.

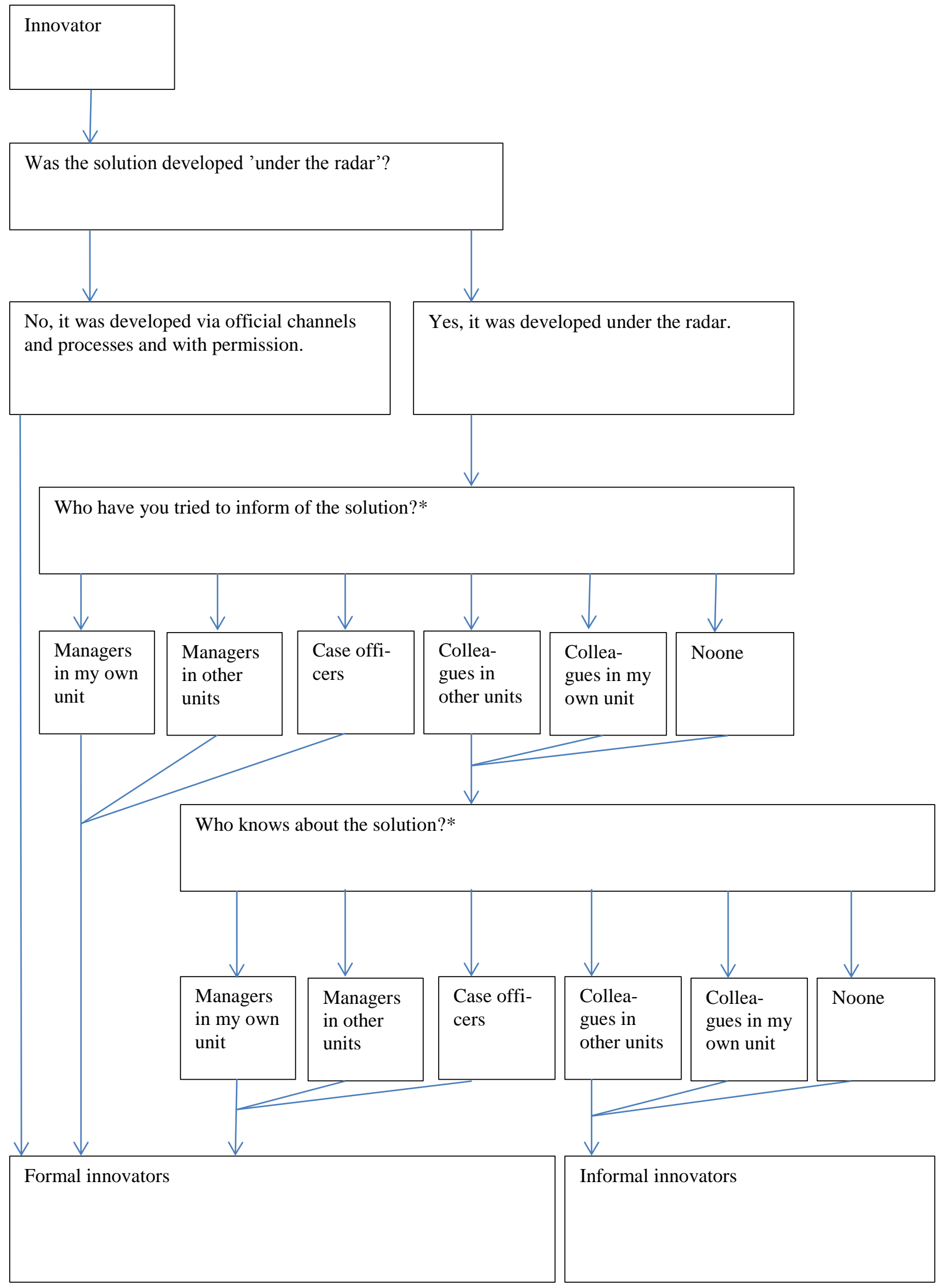


Table 6: Share of informal innovators

\begin{tabular}{|c|c|c|c|c|c|c|c|c|c|c|c|c|}
\hline & \multicolumn{3}{|c|}{ Metro } & \multicolumn{3}{|c|}{ Alpha } & \multicolumn{3}{|c|}{ Bravo } & \multicolumn{3}{|c|}{ Total } \\
\hline & \# & $\mathrm{n}$ & $\%$ & \# & $\mathrm{n}$ & $\%$ & $\#$ & $\mathrm{n}$ & $\%$ & $\#$ & $\mathrm{n}$ & $\%$ \\
\hline $\begin{array}{l}\text { Have developed 'under } \\
\text { the radar' }\end{array}$ & 21 & 22 & 95.5 & 17 & 22 & 77.3 & 27 & 28 & 96.4 & 65 & 72 & 90.3 \\
\hline $\begin{array}{l}\text { Have not shared with } \\
\text { managers }\end{array}$ & 12 & 20 & 60.0 & 15 & 21 & 71.4 & 16 & 26 & 61.5 & 52 & 69 & 75.4 \\
\hline $\begin{array}{l}\text { Innovations are not } \\
\text { known by managers }\end{array}$ & 17 & 22 & 77.3 & 18 & 23 & 78.3 & 17 & 28 & 60.7 & 47 & 71 & 66.2 \\
\hline Informal innovators & 11 & 20 & 55.0 & 11 & 21 & 52.4 & 14 & 26 & 53.8 & 36 & 69 & 53.7 \\
\hline
\end{tabular}


Table 7: Sharing and adoption of innovations

\begin{tabular}{|c|c|c|c|c|c|c|c|c|c|c|c|c|}
\hline & \multicolumn{3}{|c|}{ Metro } & \multicolumn{3}{|c|}{ Alpha } & \multicolumn{3}{|c|}{ Bravo } & \multicolumn{3}{|c|}{ Total } \\
\hline & \# & $\mathrm{n}$ & $\%$ & \# & $\mathrm{N}$ & $\%$ & \# & $\mathrm{n}$ & $\%$ & $\#$ & $\mathrm{n}$ & $\%$ \\
\hline $\begin{array}{l}\text { Innovation shared with } \\
\text { peers in own unit }\end{array}$ & 14 & 20 & 70.0 & 12 & 21 & 57.1 & 17 & 26 & 65.4 & 43 & 67 & 64.2 \\
\hline $\begin{array}{l}\text { Innovation shared with } \\
\text { peers in other units }\end{array}$ & 7 & 20 & 35.0 & 4 & 21 & 19.0 & 5 & 26 & 19.2 & 16 & 67 & 23.9 \\
\hline $\begin{array}{l}\text { Innovation adopted by } \\
\text { peers in own unit }\end{array}$ & 10 & 14 & 71.4 & 13 & 17 & 76.5 & 15 & 25 & 60.0 & 38 & 56 & 67.9 \\
\hline $\begin{array}{l}\text { Innovation adopted by } \\
\text { peers in other units }\end{array}$ & 8 & 14 & 57.1 & 5 & 17 & 29.4 & 5 & 25 & 20.0 & 18 & 56 & 32.1 \\
\hline
\end{tabular}


Table 8: Motives for developing solution under the radar

\begin{tabular}{|c|c|c|c|c|c|c|c|c|}
\hline & \multicolumn{2}{|c|}{ Metro } & \multicolumn{2}{|c|}{ Alpha } & \multicolumn{2}{|c|}{ Bravo } & \multicolumn{2}{|c|}{ Total } \\
\hline & \# & $\%$ & \# & $\%$ & \# & $\%$ & \# & $\%$ \\
\hline $\begin{array}{l}\text { I could not wait for a solution to be developed for- } \\
\text { mally }\end{array}$ & 7 & 33.3 & 6 & 35.3 & 17 & 63.0 & 30 & 46.2 \\
\hline I did not know how to get it developed formally & 9 & 42.9 & 5 & 29.4 & 5 & 18.5 & 19 & 29.2 \\
\hline $\begin{array}{l}\text { My managers are not interested in the problem or do } \\
\text { not understand it }\end{array}$ & 4 & 19.0 & 4 & 23.5 & 7 & 25.9 & 15 & 23.1 \\
\hline I am not allowed to use solutions like it & 2 & 9.5 & 0 & 0.0 & 3 & 11.1 & 5 & 7.7 \\
\hline I am not allowed to develop solutions like it & 2 & 9.5 & 0 & 0.0 & 1 & 3.7 & 3 & 4.6 \\
\hline $\begin{array}{l}\text { I am not allowed to spend working time developing } \\
\text { solutions like it }\end{array}$ & 0 & 0.0 & 0 & 0.0 & 1 & 3.7 & 1 & 1.5 \\
\hline $\begin{array}{l}\text { I am not allowed t use materials from my workplace } \\
\text { to develop solutions like it }\end{array}$ & 0 & 0.0 & 1 & 5.9 & 0 & 0.0 & 1 & 1.5 \\
\hline I lacked the formal resources to develop the solution & 0 & 0.0 & 0 & 0.0 & 1 & 3.7 & 1 & 1.5 \\
\hline Other & 6 & 28.6 & 5 & 29.4 & 5 & 18.5 & 16 & 24.6 \\
\hline $\mathrm{N}$ & 21 & 100.0 & 17 & 100.0 & 27 & 100.0 & 65 & 100.0 \\
\hline
\end{tabular}


Figure 4: Working time spent $(n=58)$

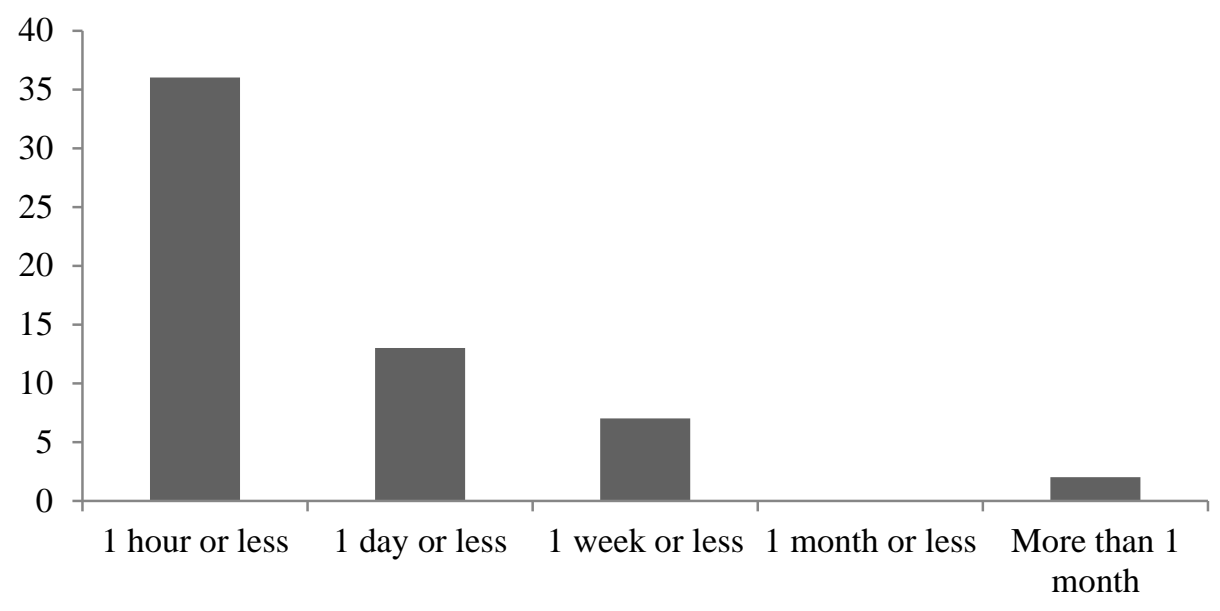


Figure 5: Free time spent $(n=53)$

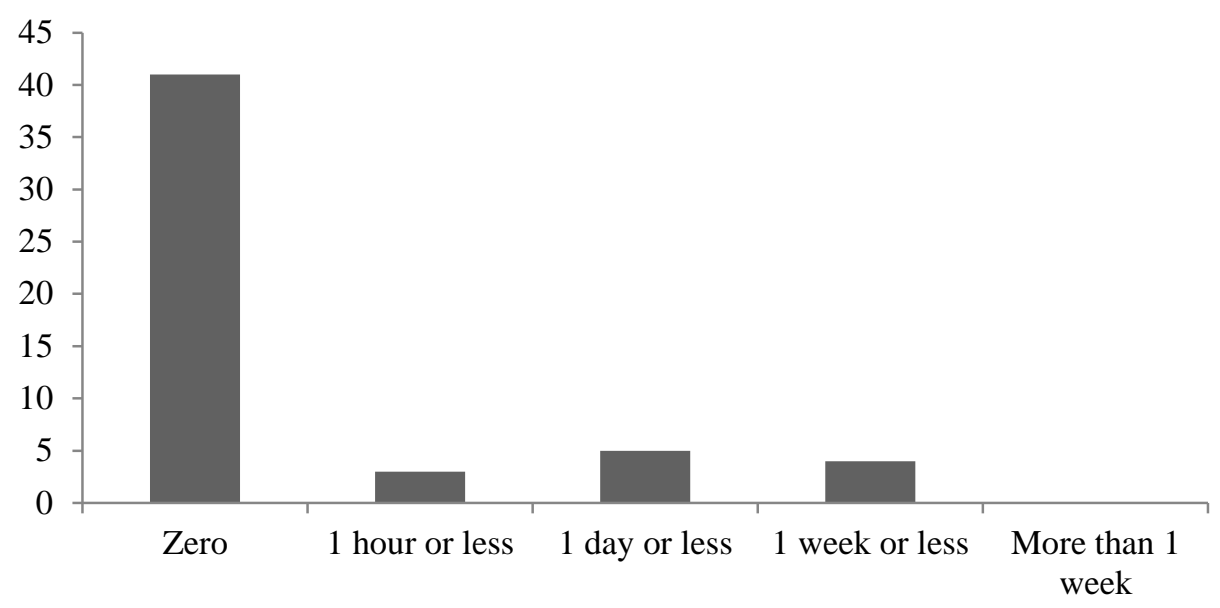


Figure 6: Money spent. in DKK $(n=59)$

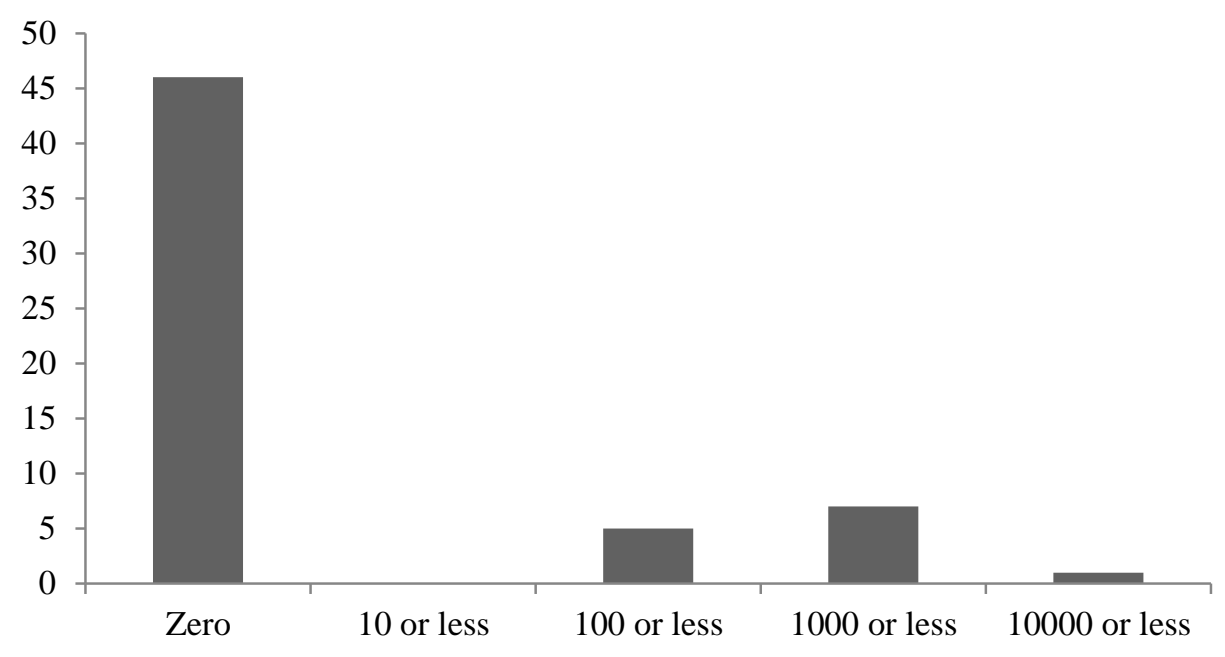


Picture 13a: Flashlight holder

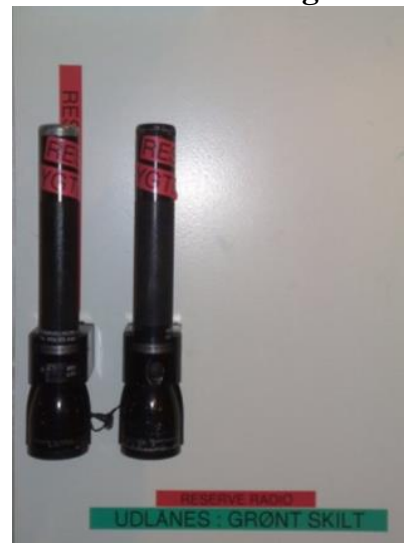

Picture 13b: Flashlight holder

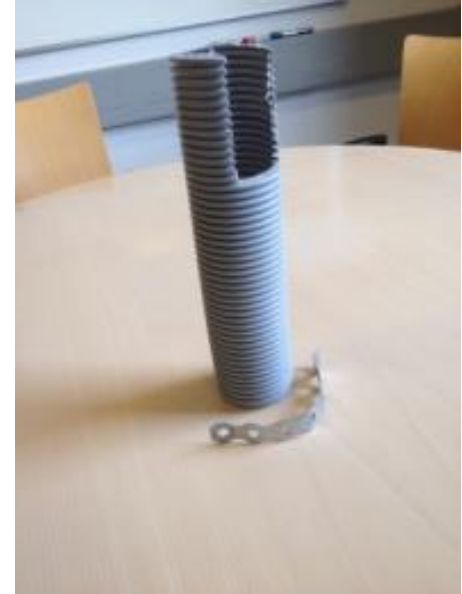


Figure 7: Potential improvement (in percent) of innovation. given all desired resources $(\mathbf{n}=65)$

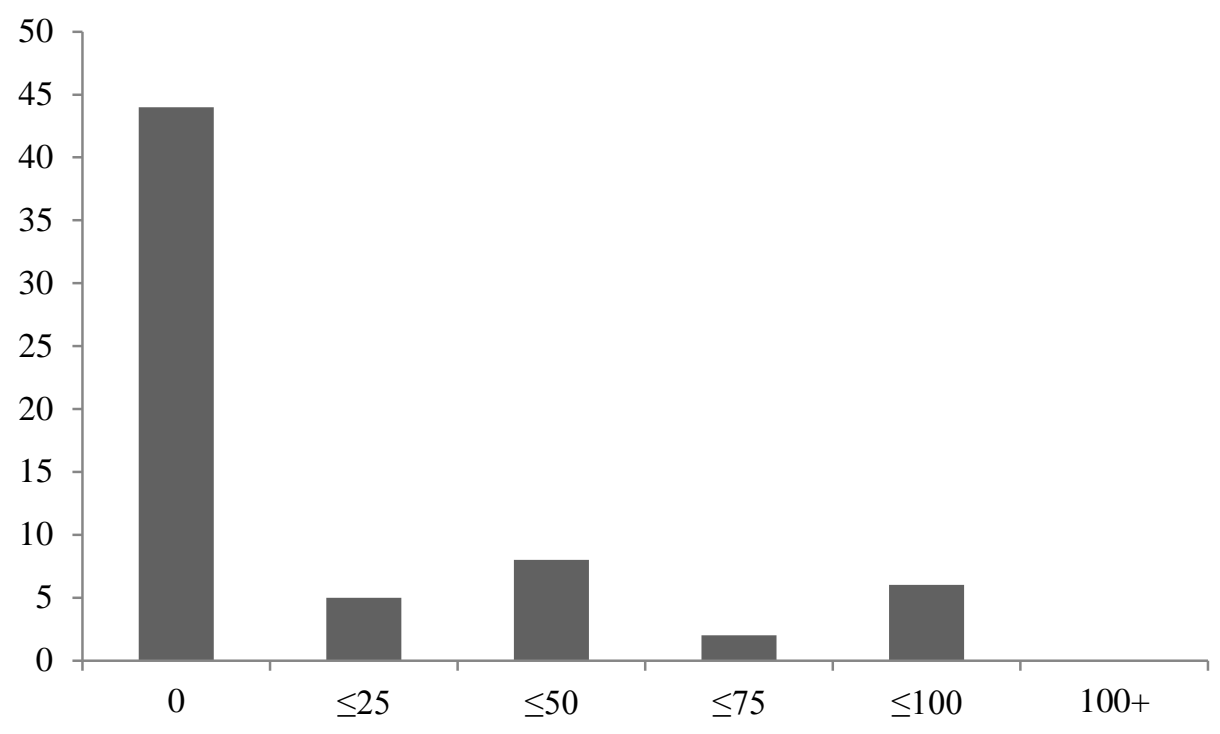


Table 9: Expert evaluation of innovations

\begin{tabular}{|c|c|c|c|c|c|c|c|c|}
\hline \multirow[b]{2}{*}{ Questions (scales 1 to 7) } & \multicolumn{4}{|c|}{ Police $(n=40)$} & \multicolumn{4}{|c|}{ Military $(\mathrm{n}=56)$} \\
\hline & Mean & $\% 5<$ & $\begin{array}{l}\text { Avg. } \\
\text { max- } \\
\min \end{array}$ & Fleiss $\kappa$ & Mean & $\% 5<$ & $\begin{array}{c}\text { Max- } \\
\min \end{array}$ & $\begin{array}{c}\text { Fleiss } \\
\kappa\end{array}$ \\
\hline $\begin{array}{l}\text { How important is this solution to the devel- } \\
\text { oper's work? }\end{array}$ & 5.0 & 50.0 & 3.0 & -0.1 & 3.3 & 3.6 & 3.5 & 0.0 \\
\hline $\begin{array}{l}\text { How valuable would this solution be for } \\
\text { others in the developer's organization? }\end{array}$ & 4.7 & 42.5 & 3.4 & -0.1 & 3.3 & 3.5 & 2.9 & 0.0 \\
\hline $\begin{array}{l}\text { If this solution were implemented as a } \\
\text { standard, how much would it contribute to } \\
\text { reductions in resource use? }\end{array}$ & 3.8 & 15.0 & 3.9 & $-0.1 * *$ & 2.4 & 0.0 & 2.7 & 0.0 \\
\hline $\begin{array}{l}\text { If this solution was implemented as a stand- } \\
\text { ard, how much would it contribute to im- } \\
\text { provements in the safety of the user and } \\
\text { others? }\end{array}$ & 3.6 & 17.5 & 3.3 & 0.0 & 2.5 & 0.0 & 2.7 & 0.0 \\
\hline $\begin{array}{l}\text { If this solution was implemented as a stand- } \\
\text { ard, how much would it contribute to im- } \\
\text { provements in performance quality? }\end{array}$ & 4.6 & 37.5 & 3.5 & $-0.1 * * *$ & 3.2 & 1.8 & 2.8 & 0.0 \\
\hline $\begin{array}{l}\text { If this solution was implemented as a stand- } \\
\text { ard, how much would it contribute to im- } \\
\text { provements in service quality for citizens? }\end{array}$ & 3.4 & 27.5 & 2.3 & $0.3 * * *$ & & & & \\
\hline
\end{tabular}


Picture 14: 'Korean' winter hat (picture courtesy of www.policemedia.dk)

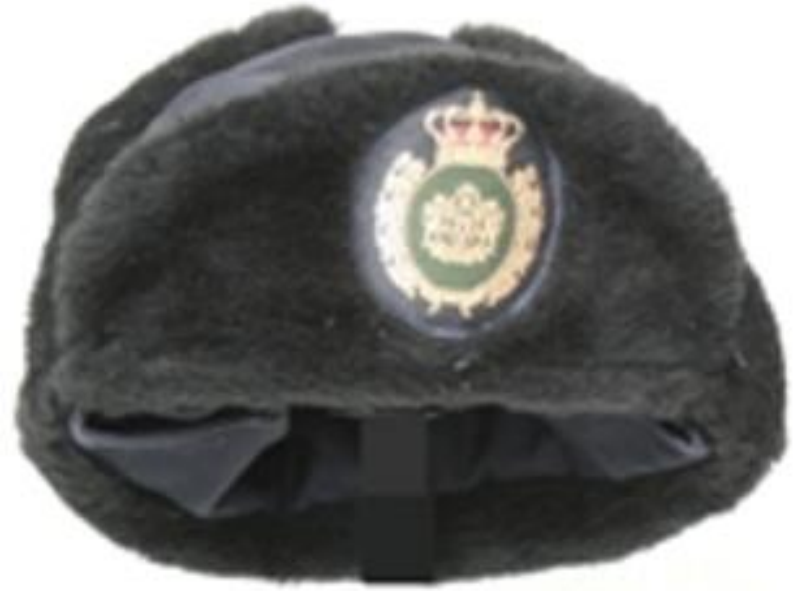

